dergİabant (AİBÜ İlahiyat Fakültesi Dergisi), Güz 2020, Cilt:8, Sayı:2, 8:488-517

Geliş Tarihi: 20.06.2020 Kabul Tarihi: 26.11.2020

Araștırma Makalesi

Doi: https://doi.org/10.33931/abuifd.755501

\title{
Necm Sûresi ve İhtiva Ettiği Belâğî Sanatlar
}

\section{Ferit Dinçer*}

Öz

Kur'ân'da bulunan ve her biri genel itibariyle besmele ile ayrılan bölümlere sûre diye isimlendirilmiştir. Buna binaen Kur'ân'da yüz on dört sûre bulunmaktadır. Bu sûrelerden birisi de bu kısa çalışmanın da konusu olan Necm Sûresidir. Adını ilk âyette geçen $\mathrm{Necm}$ lafzından alan sûre, âlimlerin kahir ekseriyetine göre Mekke döneminde İhlas'tan sonra Abese'den önce inmiştir. Başında kasem harfi vâv bulunduğundan "ve'n-Necm" olarak da isimlendirilmiștir. Sûre, altmıș iki âyetten müteșekkil olup " I, o, ن,, , ى," gibi harfler fasıla harfleridir. Mushaf'taki sıralamada elli üçüncü, nüzul sırasına göre ise yirmi üçüncü sûre olan, nüzul sırasına göre içinde secde âyeti bulunan ve $\mathrm{Hz}$ Muhammed'in (s.a.v.), Kâbe'de açıktan okuduğu ilk sûredir. Okuma esnasında secde etmiștir. Onun okumasını duyan hazirun (orada bulunan; insan, cin, Müslüman ve müşrikler) da ona uyarak secde etmişlerdir. Yine sûrede bulunan konular, insanın zihin ve gönül dünyasına belâĝî ve etkileyici bir ifade üslubuyla aktarılmıştır. Bu nedenle ele alınan bu kısa çalışmada, sûrenin kimliği ve özellikle ihtiva ettiği konuları aktarma üslubundaki belâğî sanatlar tespit edilip üzerinde durulacaktır.

Anahtar Kelimeler: Arap Dili, Belâgat, Kur'ân, Sûre, Necm Sûresi.

\section{The Chapter of Necm and the Belâğî Arts It Contained}

\begin{abstract}
The chapters in the Quran, each of which are generally separated by basmala, are named as surah. Therefore, there are one hundred and fourteen suras in the Quran. One of these surahs is the chapter of Necm, which is the subject of this short study. The surah, which takes its name from the word Najm mentioned in the first verse, descended before Abasa after Ihlas in the Mecca period according to the dire majority of scholars. It is also named as "and'n-Necm" because it has the letter vawa at the beginning. The surah consists of sixty-two verses and the letters such as ", ا, ,و," are the letters of the interval. It is the fifty-third surah in the order in Mushaf and the twenty-third surah in the order of nuzul, which has a verse of prostration in the order of nuzul, and is the first surah that Prophet Muhammad (pbuh) read openly in the Kaaba. He prostrated while reading. The ready-to-be (people, jinn, Muslims and polytheists there) who heard him read also prostrated by obeying him. Again, the subjects in the surah are conveyed to the world of mind and heart of man in a eloquent and impressive style of expression. For this reason, in this short study, the identity of
\end{abstract}


the surah and especially the eloquent arts in the style of conveying the subjects it contains will be determined and emphasized.

Keywords: Arabic Language, Rhetoric, Quran, Sura, Najm Sura.

\section{Giriş}

Nazil olduğundan bu güne kadar sûrelerin tefsiri ile alakalı müstakil çalışmalar kaleme alınmıștır. Bu baptan olmak üzere Fatiha, Yasin, Fetih ve Mülk gibi sûrelerin tefsiri yapılmış, akademik çevrelerce de birçok sûrenin çalıșması yapılmıș ve söz konusu sûreleri farklı açıdan değerlendirmişlerdir. Ancak sûrelerin belâgati ile ilgili çalışma çokaz yapıldığından bu konuda bir nüve olmak amacıyla böyle bir çalışma yapılmaya karar verildi. Bu çalışma için Necm sûresinin tercih edilmesi ise, özet bölümünde de ifade edildiği gibi açıktan okunan, içinde secde âyeti bulunan ilk sûre olması, "Garanik" diye anılan olayla ilişkilendirilmesi gibi birçok özelliğinin olması ve belâgatın birçok sanatını ihtiva etmesindendir.

Necm sûresi, cumhurun görüşüne göre 32. âyeti dışında, Mekkî bir sûredir. ${ }^{1}$ Tamamının ya da bir kısmının Medenî olduğunu iddia eden olsa da sûredeki mevcut konular ve anlatım üslubu ile öncesi ve sonrasıyla olan sıkı anlam bağı, söz konusu iddiayı tereddütlü kılmaktadır. ${ }^{2}$ İslam inancının üç ana esasından meydana gelensûredeki sıraya göre- nübüvvet, tevhit ve âhiret hayatını konu edinen sûrenin içeriğini bu çerçevede incelemek mümkündür. Hz. Muhammed'in (s.a.v.) hak peygamber, Kur'ân'ın da vahiy mahsulü olduğunu bildiren birinci pasaj, -verilecek emir ve nehiylere dikkat çekmek- hem Kur'ân'ın ilk muhatabı olan Arap topluluğu hem de sonraki insanlar için ehemmiyetli bir gök cismi olan yıldıza kasemle başlar. Sonra yakınlık ve muhabbet vesilesi olması babından olmak üzere "arkadaşınız" șeklinde nitelenen Hz. Muhammed'in (s.a.v.) müşriklerin iddiasının tam tersine hak ve dürüstlük yolundan ayrılmadığı bildirilir. Hz. Peygamber'in (s.a.v.) ulaștırdığı konuların kendi fikir ve duygusunun mahsulü değil, Yüce Allah katından gelen vahiy olduğu ifade edilir. Sonraki pasajda, cahiliye döneminden itibaren tapınılan ve Allah'ın kızları oldukları iddia edilen Lât, Uzzâ ve Menât adındaki putlar zikredilmiştir. Ardından, kız babası olmayı kabullenemeyen putperestlerin dişi tanrılara ibadet etmelerinin mantıksızlığına değinilir ve onların insanlara hiçbir

Ebû'l-Kāsım Mahmûd b. Ömer ez-Zemaherî, Tefsîru'l-Keşşâf 'an hakāiki ġavâmidi't-tenzîl ve 'uyuni'l-ekāvîli fî vucuhi't-te'vîl, thk. Adil Ahmed Abdulmevcud - Ali Muhammed Mu avid, (Riyad: Dârü'l-Abikân, 1998), 5/633; Ebû Abdillah Muhammed b. Ahmed b. Ebî Bekir b. Ferh el-Kurtubî, el-Câmi' li Ahkâmi'l-Kur ân, thk. Abdullah b. Abdülmuhsin et-Türkî, (Beyrût: Müessesetü'r-Risâle, 1427/2006); 20/5; Ebû Hayyân Muhmmed b. Yusuf el-Endelûsî, el-Bahru'l-muhîț, thk. Adil Ahmed Abdulmevcud - Ali Muhammed Mu avid, (Beyrut:Dârü'l-Kütübi'l- đ̇lmiyye, 1413/1993), 8/154; Ebû Abdillah Celâlüddîn Muhammed b. Ahmed b. Muhammed en-Ensârî el-Mahallî, Ebü'l-Fazl Celâlüddîn Abdurrahmân b. Ebî Bekir b. Muhammed el-Hudayrî es- Süyûtî eș-Şâfiî, Tefsîru'l-celâleyn, 14. Baskı, (Dımaşk: Dârü İbn Kesîr, 1431/2011), 526; Abdu'l-Muteal es-Sa îdî, en-Nażmu'l-Fenniyyu fi'l-Kur'ân, (Kahire: Mektebetü'l-Âdâbi li'n-Neșri ve't-Tevzî‘', 1439/2018), 298-299.

2 Kurtubî, el-Câmic li Ahkâmi'l-Kur'ân, thk. Abdullah b. Abdülmuhsin et-Türkî, 20/5; Muhammed İzzet ed-Derveze, et-Tefsîrü'l-ḥadîs, (Kahire: Dârü'l-Ġarbi'l-İslâmî, 2000), 2/74; Muhammed elEmîn b. Abdullah el-Uremî el-Alevî el-Herarî, Hadâiku'r-ravhîi ve'r-rayhâan, thk. Hâş̧em Muhammed Ali b. Hüseyin Mehdî, (Mekke: Dârü't-Tavkư'n-Necât, 1421/2001), 28/100. 
yararları dokunamayacağı ifade edilir. Sûrenin son pasajı ise sadece dünya hayatını düşünerek başka bir derdi ve emeli olmayan, sağlam ve tutarlı ilimden yoksun olup yalnızca tahmin ve zanna istinaden, öbür hayatı (ahiret) görmezden gelen ve meleklere dişilik yakıştırıp bu nitelikte buldukları tağutlara secde ettiklerinin tespitiyle başlar. Sonra kâinatta bulunan her şeyin mülk ve hâkimiyetinin Yüce Allah'a ait olduğu, insanoğlunu yoktan var eden, üreme kanununu koyan Cenâb-ı Hakk'ın, insanları dünyada işlediklerinden sorumlu tutacağı dile getirilir. Daha sonra eski ümmetlerin, Peygamberlerinin tebliğine kulak asmayıp iman etmemelerinden dolayı çeşitli afetlerle helak olduklarını, kıyametin yaklaştığı ancak ne zaman vuku bulacağını sadece Allah'ın bilebileceği, müşriklerin Allah'ın kelamı karşısında laubali davranmamaları gerektiği anlatılır. ${ }^{3}$

\section{Necm Sûresinin Kimliğiyle İlgili Bilgiler}

Bu başlık altında Necm sûresinin ismi, nüzul sebebi ve diğer sûrelerle münasebeti, garânîk olayının aslı gibi konular yer almaktadır.

\section{1. Sûrenin İsmi ve Nüzul Sebebi}

Sûrelerin bazıları isimlerini, sûrede geçen garip bir kelimeden ya da o kelimenin ifade ettiği anlamdan alırlar. ${ }^{4}$ Bu nedenle sûrelerin bir kısmı birden fazla isme sahip olabilmektedir. ${ }^{5}$ Kıssa ihtiva eden bazı sûreler isimlerinin kıssada zikri geçen peygamberden alır. ${ }^{6}$ Kavim ve kabileden bahseden bazı sûreler ise isimlerini bu kavim ve kabilelerden alır. ${ }^{7}$ Ancak burada şunu da belirtmekte fayda var; sûrelerin, ihtiva ettikleri mevzulara göre, adlandırılması zorunlu ve şart değildir. ${ }^{8}$ Çalışmanın konusu olan sûre ise ismini, başında geçen ve âlimlerin kahir ekseriyetine göre "Yıldız" anlamında kullanılan "النّجم" kelimesinden almaktadır.9

3 Bedruddin Muhammed b. Abdullah ez-Zerkeșî, el-Burhân fî 'ulûmi'l-Kur'ân, thk. Yusuf Abdurrahman vd., (Lubnan: Dârü'l-Me'ârife, 1410/1990), 1/179; Süyûtî, el-ítkāan fì 'ulûmi'lKur'ân, (Beyrut: Müessesetü Risâletu Nâşirün, 1469/2008), 525; Derveze, et-Tefsîrü'l-ḥadîs, 2/74; Herarî, Hadâik, thk. Hâşem Muhammed Ali b. Hüseyin Mehdî, 28/100.

4 Süyûtî, el-ïtkān, 125.

5 Örneğin, Enfâl, İsrâ, Neml ve Fâtır gibi sûrelerinin birçok ismi bulunmaktadır. Hatta Fatiha sûresinin yirmiden fazla ismi vardır (Süyûtî, el-ítkān, 119-125).

6 Buna; Nuh, Hûd, İbrâhîm, Yusuf ve Muhammed sûreleri örnek vermek mümkündür (Süyûtî, elİtkān, 125-126).

7 Buna; Kasâs, el-Melâike, el-Cin, el-Münafikûn ve el-Mutaffifûn sûreleri örnek verilebilir (Süyûtî, el-ítkān, 126).

8 Örneğin, Mûsâ Peygamberin kıssası ve ismi; Tâhâ, Kasâs ve A'raf sûrelerinde geçmesine rağmen, bunlara "Mûsâ" diye isim konulmamıștır (Süyûtî, el-İtkān, 126).

9 Bazı âlimlere göre, “النّج” kelimesinden maksat; Kur'ân, gövdesi olmayan bitki, Kur'ân'ın tencimi (peyderpey, kademeli inmesi ) veya Hz. Muhammed'dir (bk. Ebû Cafer Muhammed b. Cerîr b. Yezîd et-Taberî, Câmi'u'l-beyân 'an te'vîli âyi'l-Kur'ân, thk. Abdullah b. Abdulmuhsin et-Türkî, (Dârü'l-Hicir, 1422/2001), 22/5-7; Zemaherî, el-Keșşâf, thk. Adil Ahmed Abdulmevcud - Ali Muhammed Mu'avid, 5/633-634; Ebû'l-Hasen Alâüddîn Ali b. Muhammed b. İbrâhîm b. el-Hâzin el-Bağdâdî, Lübâbü't-te'vil fî me`anî't-tenzîl, (Mısır: Nezâretu'l-Me'arif, 1327/1909), 4/181; Ebû'lFidâ İsmail b. Ömer b. Kesîr, Tefsîru'l-Kur'ân'il-'Azîm, thk. Mustafâ es-Seyyid Muhammed vd., (Kahire: Mektebetü Evlâdi eș-Șeyh li't-Turâs, 1421/2000), 13/247). 
Kur'ân'ın ihtiva ettiği hususları gereği gibi anlamak ve mantıklı bir sonuca ulaşabilmek için, vahiy sürecini ve bu süreçte meydana gelen gelişmeleri, daima dikkatli bir şekilde takip etmek gerekmektedir. Bu, Necm sûresi için de geçerli olduğundan sûrenin nüzul sebebi de aynı mantıkla, daha önceki vahiy sûreci dikkate alınarak izah edilecektir.

Diğer insanlardan kendini farklı görmeyerek sade bir hayat tarzını benimseyen Hz. Muhammed'in (s.a.v.), bir gün Mekkelilerin huzuruna çıkarak Allah tarafından peygamber olarak gönderildiğini ve kendisine vahiy nazil olduğunu ifade etmiş, buna karşılık Mekkeliler, onun sapıttığı, cinlendiği ve delirdiği iddiasında bulunmuşlar. Diğer taraftan Hz. Muhammed'in (s.a.v.), Allah katından vahiy yoluyla kendisine verilen Kur'ân'ı da hevâsına, kuruntusuna ve çıkar beklentilerine kapılarak uydurduğunu iddia etmişlerdir. İște tam da bu sırada Necm sûresi inmiş, Mekke müşriklerinin iddia ettikleri tüm safsataları tersyüz ederek yalanlamış, $\mathrm{Hz}$. Muhammed'in (s.a.v.), ifade ettiği her şeyin gerçek, Rabbi tarafından kendisine bahşedildiğini doğrulamış ve bunu bir şamar gibi yüzlerine vurmuştur. Sûre, Hz. Muhammed'in (s.a.v.), vahyi ne şekilde, hangi zaman ve mekânda almaya başladığını Arap toplumunun aşina olduğu dil ve üslupla açılamış, müşriklerin ileri sürdükleri inkâra dayalı ithamlara, kanıtlar göstererek cevap vermiştir. ${ }^{10}$

Sûrenin bir bütün şeklindeki nüzul sebebi bu şekilde iken, sûre içindeki bazı âyetlerin de müstakil nüzul sebebi olduğu yönünde rivâyetler zikredilmiştir. Bunlardan bazıları şöyledir:

İbn Münzir (öl. 318/930), İbn Ebî Hatim (öl. 327/938), Taberânî (öl. 360/971) ve Vahidî (öl. 468/1076), şöyle bir rivâyet aktarmışlar: "Yahudiler, küçük çocukları öldügü zaman 'o Sıddık'tır' diyorlardı. Bu sözleri Resulüllah'a ulaştığında şunları söyledi, 'Yahudiler yalan söylemişler. Allah'ın yaratmış olduğu hiçbir nefis yoktur ki ya saîd ya da şaki olmasın. Yani o nefis ya şakidir ya da saîddir' bu olay üzerine Necm sûresinin 32. âyeti nazil olmuştur."11

Müfessir Zemahşerî (öl. 538/1144) ise söz konusu âyetin nüzul sebebini farklı bir şekilde aktarmıştır: "Denilmiştir ki bazı şahıslar; Namaz, oruç ve hac gibi iyi bir amel işledikleri zaman, 'benim namazım, benim orucum, benim hacım' şeklinde dillendiriyorlardı. İşte bundan dolayı Yüce Allah bu âyeti nazil etti."12

\footnotetext{
10 Taberî, Câmi ‘u'l-beyân, thk. Abdullah b. Abdulmuhsin et-Türkî, 22/8-10; Herarî, Hadâik, thk. Hâșem Muhammed Ali b. Hüseyin Mehdî, 28/102-103.

11 Söz konu âyetin metni ve meâli şu şekildedir: “

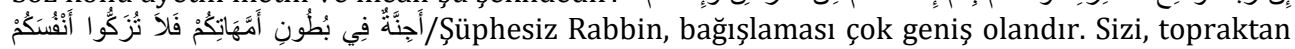
yarattığında da ve analarınızın karnında ceninler iken de, en iyi bilendir. Bunun için kendinizi temize çıkarmayın." (Bk. Ebû'l-Hasan b. Ali b. Ahmed b. Muhammed el-Vahidî en-Nîsâbûrî, Esbâbu'n-nüzul, thk. Usam b. Abdulmühsin, 2. Baskı, el-Humeydân, (ed-Demmam: Dârü'l-Islâh, 1416/1992), 415; Süyûtî, Lübâbu'n-nükūl fî esbâbi'n-nüzul, Beyrut: Müessesetu'l-Kütübi'lSekāfiyye, 1422/2002, 247). 
İbn Ebî Hatim, İkrime'den (öl. 13/634) şunları rivâyet etmiştir: “Allah Resulü, bir savaşa çıkmak üzereyken, bir adam gelerek Resulüllahtan kendisine bir binek verilmesini istemiştir. Ancak Resulüllah'ın kendisine verilecek bineği olmadığını anlayınca, bir dostundan bu ihtiyacının giderilmesini talep etmiş ve dostu da 'şâyet benim günahlarımı yüklenirsen devemi sana vereceğim demiş’ adam da kabul etmiş ve bu diyalogdan sonra Necm sûresinin 33. âyeti nazil olmuştur."13

\section{2. Sûrenin Önceki ve Sonraki Sûrelerle Münasebeti}

Cenâb-ı Allah tarafından nazil olunan Kur'ân-ı Kerîm, tutarsızlık ve çelişkiden beri olan bir vahiy mahsulüdür. ${ }^{14}$ Kur'ân'ın bütününde olduğu gibi, onun sûreleri arasında da güçlü bir tutarlılık ve insicam olduğuna hiç şüphe yoktur. Nitekim sûre ve âyetler arasındaki tenasüp ilminin, şerefli bir ilim olduğu birçok âlim tarafından ifade edilmiştir. ${ }^{15}$ Sûreler arasındaki insicam ve münasebet ile alakalı bilgi, birçok tefsirde mevcut olmasına karşın, konu hakkında müstakil çalışmalara da rastlamak mümkündür. ${ }^{16}$

Necm sûresinin, kendisinden önceki Tur ve sonrasındaki Kamer sûreleri ile münasebet ve insicamı, şu şekilde ifade edilebilir.

\section{2. 1. Tur Sûresi ile Münasebeti}

Necm sûresinin öncesinde geçen "Tur" sûresi ile münasebet ve insicamı hem lafzen hem de manen olduğu açıktır.17

Tur sûresi "nucum/necm” "kelimesiyle sonlandırılırken Necm sûresi aynı kelime ile "و النّجم" diye başlatılmıştır. Tur sûresinde müşriklerin Kur’ân hakkında; "o şiirdir, uydurulmuş sözdür, kâhin ve anormal bir kişinin sözüdür" şeklindeki iftiralara yer verilmiş ve bu iftiraları "Tevbîh" denilen istifam üslubuyla kesin bir şekilde reddedilmiştir (ام يقولون تقوّله). Necm sûresinde de aynı şekilde, Kur'ân'ın hevâ mahsulü olmadığı, Hz. Muhammed'in ise sapmadığı ve eğri yola girmediği, Kur'ânî bir üslup olan kasem ifadesiyle kesin olarak reddedilmiştir. Dolayısıyla her iki sûrede de Hz. Peygamber ve Kur'ân ile ilgili asılsız iddia ve isnatlar, kesin bir dille

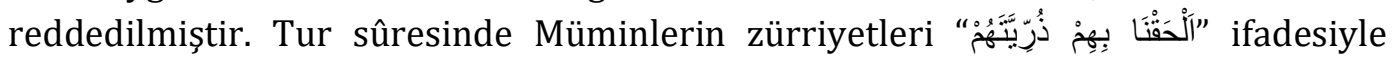
kendilerine ilhak olunacağı dile getirilmiştir. Necm sûresinde de kâfirler hakkında

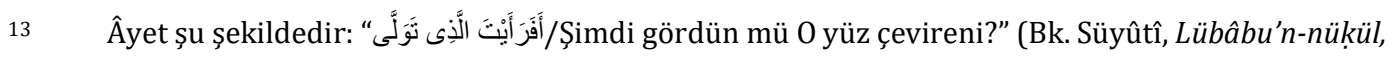
247; Vahidî en-Nîsâbûrî, Esbâbu'n-nüzul, thk. Usam b. Abdulmühsin, 398).

14 Söz konusu olan gerçeği, Kur'ân şu şekilde te'yid etmektedir: "Kur'ân'ı düşünmüyorlar mı? Şâyet Allah'tan başkası katından nazil olmuş olsaydı, ondan birçok ihtilaf bulurlardı." (Nisâ, 4/82).

15 Zerkeşî, el-Burhân, 1/35; Süyûtî, el-ítkān, 630-631.

16 Bk. Süyûtî, el-İtkān, 1469/2008), 630-631; İsmail Cerahoğlu, Tefsîr Usulü, (Ankara: 1993), 206207; Muhsin Demirci, Tefsîr Usulü, 23. Baskı, (İstanbul: İFAV. Yayınları, 2013), 191-195.

17 Bk. Ebû Abdillah Fahruddîn Muhammed b. Ömer Râzî, et-Tefsîru'l kebîr/Mefâtîḥu'l-ġayb. (Beyrut: Dârü'l-Fikir, 1420), 28/277. 


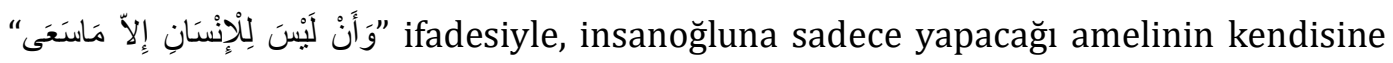
yarar vereceğini dile getirilmiştir. ${ }^{18}$

Baḥru'l-Muhit'in müellifi, iki sûre arasındaki münasebeti şu şekilde ifade etmiştir: "Necm sûresinin evveliyle münasebeti açıtırı; çünkü evvelindeki sûrede, Kur'ân'a uydurulmuş söz ve şiir, Hz. Muhammed'e de şair, kâhin ve mecnun denmiştir. Necm sûresinde ise Allah, Hz. Muhammed'in sapmadığı ve eğri yola girmediği yeminle reddetmiştir." 19

Son olarak şunu söylemek mümkündür; her iki sûre de Mekke döneminde nazil olmuş ve kasem ile başlatılmıștır. ${ }^{20}$

\section{2. 2. Kamer Sûresi ile Münasebeti}

Necm ile Kamer arasındaki münasebet ve insicam güçlü bir şekilde kendini göstermektedir. Zira her iki sûre de Mekke döneminde nazil olmuş, birincisi " آَزَفَتَ

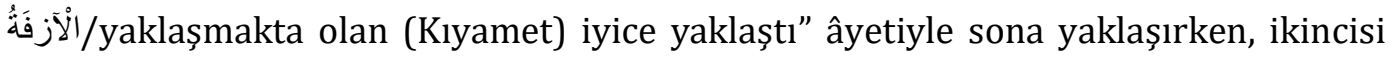

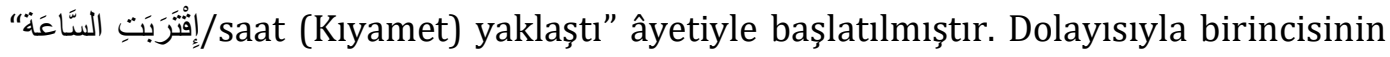
sonu ikincisinin evveli ile aynı konu hakkında bilgi vermektedir. Necm sûresinde, peygamberlerini tekzip eden ümmetlerin uğradıkları helâk ve azap, Kamer sûresinde daha detaylı bir şekilde zikredilmiştir. ${ }^{21}$

Ruhu'l-Meânî tefsirinin sahibi Âlusî (öl. 1270/1854), Süyûtî’den (öl. 911/1505) şunları nakletmiştir: "Bu iki sûre arasındaki münasebet ve tenâsük (alaka) gizli değildir. Çünkü her ikisinin isimlendirilmesinde (Necm-Kamer) münasebet olduğu gibi, ${ }^{22}$ Kamer sûresinin Necm sûresinden hemen sonra gelmesi; aynen A'râf'ın En'âm'dan, Şu'âra'nın Furkan'dan ve Saffat'ın Yâsin'den sonra gelmesi gibi önceki ümmetlerin helakinden tafsilatlı bir şekilde bahsetmektedir." 23

Bilmen (öl. 1391/1971) ise iki sûre arsında bulunan münasebeti maddeler halinde şu şekilde izah etmiştir:

Biri Necm'e diğeri de Kamer'e işaret ediyor ki, bunların arasında güzel bir alaka vardır.

18 Ebû Hayyân el-Bahr, thk. Adil Ahmed Abdulmevcud - Ali Muhammed Mu'avid, 8/154; Râzî, etTefsîru'l kebîr, 28/277; Ahmed Mustafa el-Meraği, Tefsîru'l-Merâğ î, (Mısır: Şirketu Mektebeti ve Matba'ati Mustafâ el-Bâbî el-Halebî ve Evlâduhu bi Mısır, 1365/1946), 27/41; Herarî, Hadâik, thk. Hâşem Muhammed Ali b. Hüseyin Mehdî, 28/100.

19 Ebû Hayyân el-Baḥr, thk. Adil Ahmed Abdulmevcud - Ali Muhammed Mu'avid, 8/154; Herarî, Hadâik, thk. Hâșem Muhammed Ali b. Hüseyin Mehdî, 28/100.

20 Ebû Cafer Ahmed b. İbrâhîm b. ez-Zübeyir el-Gırnatî, el-Burhân fî tertibi suveri'l- Kur'ân, thk. Muhammed Şabânî, (Fas: Vuzâretu'l-Evkạāf ve'ş-Şuuni'l-İslâmiyye, 1410/1990), 318; Meraği, Tefsîru'l-Merâğî, 27/41.

21 Ebû Hayyân el-Bahr, thk. Adil Ahmed Abdulmevcud - Ali Muhammed Mu'avid, 8/154; Meraği, Tefsîru'l-Merâğî, 27/74; Herarî, Hadâik, thk. Hâşem Muhammed Ali b. Hüseyin Mehdî, 28/191.

22 Buradaki "Necm" Yıldız, "Kamer" ise Ay ismidir. İkisi de birer gök cismi olduklarından dolayı aralarında alaka bulunmaktadır.

23 Ebû Senâ Şihâbüddîn Mahmûd b. Abdillâh b. Mahmûd el-Hüseynî el-Âlusî, Ruhu'l-Mecânî, nşr. Mahmûd Şükrî el-Âlusî el-Bağdâdî, 27/73-74. 
$\checkmark$ Necm sûresinin ahirinde klyamet yaklaştı denilmişti, Kamer sûresinin evvelinde ise saat takarrüp etti diye buyrulmuştur.

$\checkmark$ Kamer sûresinde önceki ümmetlerin kıssaları, Necm'dekinden ziyade izah edilmiş, helâkleri daha mufassalca bildirilmiştir. ${ }^{24}$

\section{3. Garânik Olayı}

Gurnuk, veya gırnîk kelimesinin çoğulu olan "garânik" kelimesi, "Kuğu, turna, beyaz su kuşu, beyaz tenli ve güzel kız" anlamına gelmektedir. Nitekim Kureyş kabilesi mensupları Kâbe'yi tavaf ederken, "Lat, Uzza ve diğer üçüncüsü Menât hürmetine, çünkü bu üçü ulu kuğulardır ve gerçekten şefaatleri umulan varlıklardır ve Allah'ın kızlardır" diyerek onları yüksek uçan kuşlara benzetirlerdi25

Garânik kelimesi, İslâm tarihine Hz. Peygamber'in müşriklerin gönlünü İslâm'a ısındırmayı arzu ettiği bir sırada şeytanın telkiniyle vahiylere Allah sözü olmayan bazı kelimeleri karıştırdığını ve daha sonra Cebrâil'in ikazıyla bundan vazgeçtiğini iddia eden rivâyetler münasebetiyle kullanılmış ve daha çok Necm sûresiyle ilişkin tartışmalara konu olmuştur. Konu hakkında birçok çalışma yapıldığından dolayı burada detaya girilmeyecektir. ${ }^{26}$

\section{Sûrenin İhtiva Ettiği Belâğî Sanatlar}

Malum olduğu üzere Kur'ân-ı Kerîm fesahât ve belâgat açısından zirveye çıkmış tek ve eşsiz bir kitaptır. Dolayısıyla ele alınan Necm sûresi de Kur'ân'ın bir bölümü olması nedeniyle birçok belâgat sanatını ihtiva etmektedir. Diğer taraftan Belâgat kelimesi genel bir isim olup içerisinde sırasıyla Me âni, Beyân ve Bedî‘ gibi sanat çeşitlerini barındırmaktadır. Çalışmanın konusu olan Necm sûresindeki belâğî sanatları tespit ederken, hangi çeşitten ise onun başlığı altında izah edilecektir.

\section{1. Méâni}

Belâgat ilminin üç bölümünden birisi me âni ilmidir. Ma`na kelimesinin çoğulu olan me`âni, bir belâgat terimi olarak, kelamın muktezâ-yı hâle yani yer ve zamana uygun olmasına dair kuralları ele alan ilimdir. ${ }^{27}$ Me âni ilmiyle öncellikle Kur'ân-ı Kerîm'in i'câz yönlerini öğrenmek amaçlanır.

Bilmen, Kur'ân'ı-Kerîm'in Türkçe Meâli Âlisi ve Tefsîri, (İstanbul: Bilmen Yayınevi, 1985), 7/425. Ebû'l-Münzir Hişâm b. Muhammed b. Sâib b. Bişr el-Kelbî el-Kûfî, Kitâbü'l-Eșnâm, thk. Ahmed Zekî Paşa, (Mısır: Dârü'l-Kütübü'l-Mısriyye, 1416/1995), 13-20.

Konu hakkında geniș bilgi için bk. Kelb, Kitâbü'l-Eșnâm, thk. Ahmed Zekî Pașa; Ebû Abdillah Muhammed b. İshâk b. Yesâr b. Hıyâr el-Mutallibî el-Kureşî, Siretu İbn İshâkk, thk. Ahmed Ferîd elMezîdî, (Beyrut: Dârü'l-Kütübü'l-'illmiyye, 1424/2004); Ebû Abdillah Muhammed b. Sa'd elBağdadî, Kitabü'ț-Ṭabakāti'l-kebîr (eț-Ṭabakāätül-kübrâ), thk. İhsân Abbâs, (Beyrut: Dârü Sâdır, 1388/1968); Ebû Muhammed Cemâllüddîn Abdülmeklik b. Hișâm b. Eyyûb el-Himyerî, esSîretü'n-nebeviyye (Sîretu İbn Hişâm), thk. Ömer Abdusselâm Tedmurî, 3. Baskı, (Beyrut: Dârü'lKitabi'l-'Arabiyye, 1410/1990); İsmail Cerrahoğlu, "Garânîk",TDV İslâm Ansiklopedisi, https://islamansiklopedisi. org.tr/garânîk. 'ulûm, thk. Abdulhamîd el-Hindâvî, (Lubnan: Dârü'l-Kütübi'l- İlmiyye, 1420/2000), 247-248; Ebû'l-Meâlî Celâlüddîn el-Hatîb Muhammed b. Abdirrahmân b. Ömer b. Ahmed el-Kazvînî, el-Î́żâh 
Çalışmanın konusu olan sûrede bulunan belâgat sanatının çeşitlerini ayrı ayrı başlık altında incelemeye çalışllacaktır.

\section{1. 1. Zamir Yerine Zahir İsmin Gelmesi}

Bazı cümlelerde isim yerine zamir gelebildiği gibi, bunun tam tersi de olabilmektedir. Yani zamir yerine isim gelebilmektedir. Bu da iki şekilde olur. Zamir yerine ya zahir bir isim ya da işaret ismi gelir. ${ }^{28}$

Çalışmanın konusu olan sûreye bakıldığında sadece bir yerde zamir yerine zahir isim gelmiştir:

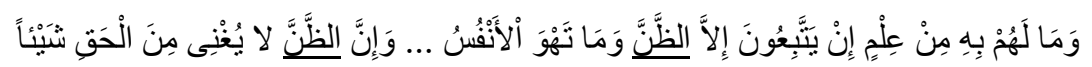

"Onların, bu konuda hiçbir bilgisi yok. Onlar ancak zanna ve nefislerin isteklerine kapılıyorlar... oysa ki zan, gerçeğe karşı hiçbir şeye yaramaz."29

Yukarıdaki âyette altı çizili ikinci “"الظََّّ" kelimesi, zamir yerine gelmiştir. Âyet

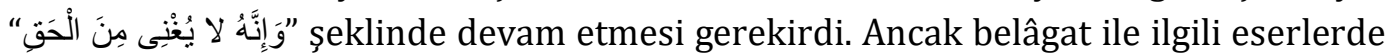
de zikredildiği üzere, bazı neden ve gayelerle zamir yerine zahir isim zikredilmiștir. ${ }^{30}$ Burada zamir yerine ism-i zahir getirilmesinin gayesi ise cins ${ }^{31}$ ifade etmek içindir.

\section{1. 2. İltifat}

İltifat/إلتفاتkelimesi sözlükte, "bir şeyi burup çevirmek, gömleğini boynuna atmak, ister tutulsun (yerine getirilsin) ister tutulmasın sözü salıvermek, görüşünden yüz çevirmek ${ }^{32}$ ve bir toplumdan uzak durmak, sağa sola bakmak, dönüp bakmak" gibi anlamlara gelir. ${ }^{33}$ "Kişinin suratını farklı açılara döndürmesi" manasına da gelebilen

fî 'ulûmi'l-belaġâ, (Beyrut: y.y., 1993), 4; Abdurrahmân Hasan Habanneke el-Meydânî, elBelâgatu'l-'Arabiyye, (Dımaşk: Dârü'l-Kalem - Beyrut: Dârü'ş-Şâmiyye, 1416/1997), 1/138-140; İn'âm Fevvâl Akkâvî, Mu'cemu'l-mufașsal fì 'ulûmi'l-belâga, thk. Ahmed Şemsüddîn, 2. Baskl, (Beyrut: Dârü'l-Kütübü'l-'illmiyye, 1417/1996), 607; Ahmed Matlûb, Mu'cemu'l-muștelehâtu'lbelấgìyye ve tețavuruhâ, (Beyrut: ed-Dârü'l-'Arabiyyetu li'l-Mevsu'ât, 1427/2006), 3/276-279. Bk. Sekkâkî, Miftâhu'l-'ulûm, thk. Abdulhamîd el-Hindâvî, 309-311; Kazvînî, el-Îżâh, 39-45; Meydânî, el-Belâġatu'l-'Arabiyye, 1/410-415; Akkâvî, Mu'cemu'l-mufașșal, thk. Ahmed Şemsüddîn, 142; Matlûb, Mu'cemu'l-muștelehâat, 1/174. Necm 53/23, 28.

Muhammed Ali es-Sâbunî, Safvetu't-tefâsîr, 4. Baskı, (Beyrut: Dârü'l-Kur'âni'l-Kerîm, 1402/1981), 3/280; Herarî, Hadâik, thk. Hâşem Muhammed Ali b. Hüseyin Mehdî, 28/157; Muhammed Hüseyin Selâme, el-í'câzü'l-belâgī fi'l-Kur'ân'il Kerîm, (Kahire: Dârü'l-Âfâkịi'l'Arabiyye, 1423/2002), 328; daha fazla bilgi için bk. Sekkâkî, Miftâhu'l-'ulûm, thk. Abdulhamîd el-Hindâvî, 309-311; Kazvînî, el-İżâh, 39-45; Meydânî, el-Belâgatu'l- 'Arabiyye, 1/410-415; Akkâvî, Mu'cemu'l-mufașșal thk. Ahmed Şemsüddîn, 142; Matlûb, Mu'cemu'l-mușțelehâat, 1/174. Cins, aralarında müşterek bağ ve nitelikler mevcut olan efradını ve alt sınıflarını kategorik olarak cem eden üst terim veya alta göre daha genel bir üst kavramdır (Ali Bardakoğlu, "Cins", TDV İslâm Ansiklopedisi, Erişim 21 Eylül 2020).

32 Ahmed b. Yusuf b. Abduddâim es-Semîn el-Halebî, 'Umdetu'l-ḥuffaz fî tefsîri eșrefi'l elfâz, thk. Muhammed Bâsil Uyunu's-Sud, (Beyrut: Dârü'l-Kütübi'l-'ỉlmiyye, 1997), 4/31; Durmuş, "İltifât", TDV İslâm Ansiklopedisi, (Erişim 19 Mayıs 2020).

33 İbn Manzûr, Ebü'l-Fazl Cemâlüddîn Muhammed b. Mükerrem b. Alî b. Ahmed el-Ensârî erRüveyfiî, "lft", Lisânu'l-'Arap, (Kahire: Dârü'l-Ma'ârif, 1119), 4052; es-Semîn el-Halebî, 'Umdetu'lhuffaz, 4/31; Kadir Güneș, Arapça - Türkçe Sözlük, (İstanbul: Mektep Yayınları, 2011), 1070 
bu kelime, Allah'ın Kelamında bu anlamda kullanılmıştır: "وَل يَلْنقَتْ مِنْكُمْ أَحَدُ /Sakın, hiç biriniz dönüp arkasına bakmasın." 34 Bu âyette etrafa bakınmaları nehiy edilmiştir. Çünkü bakınıp dururlarsa onlara azabın indirileceği bildirilmiştir. Peygamber efendimizi niteleyen bir sözde ise şöyle denir: "فإذا التفت التفت جَمِيعًا / O, birine yöneleceği zaman tüm bedeniyle yönelirdi.” yani o, gizlice bakmazdı, bir şeye baktığında ona sadece boynunu sağa sola çevirerek değil bütün bedenini çevirerek bakardı. ${ }^{35}$ Arap sözlerinden olan "وامرأة لفوت" ifadesi, " kocasından yüz çevirip başkasından olan çocuğuna yönelen kadın" için kullanılır. ${ }^{36}$ Eşyaya çok meyilli olan ve ikide bir eşyalarına bakan kadın için de "لفوت" ifadesi kullanılır. ${ }^{37}$

Belâgat ile uğraşan âlimlerin görüşüne göre, edebî sanatlardan olan iltifat, herhangi bir metinde ani bir şekilde kişisel, zamansal ve üslûbî açıdan farklılıkların meydana gelmesidir. İltifattan amaç ise yeksanlığı ortadan kaldırarak karşıdakinin dikkatini çekmektir. ${ }^{38}$

İbnü'l-Esîr (öl. 637/1239) ise, iltifât için yukarıda geçen tanımlara benzer tanımlar yaptıktan sonra "Arap yiğidi" şeklinde de isimlendirildiğini söylemiş ve bunu, şu şekilde açıklamıştır: "Yiğit kişi; başkasının yapamadığını yapar, kimsenin cüret edemediği tehlikelere ve maceralara atılır. İltifat sanatı da bunun gibi bir anda üslûp değiştirerek başka üslûba girdiği için yiğit kişiye benzer. Bu da sadece Arap diline özel bir kullanım olması nedeniyle yukarıda geçen isimlendirmeye layık görülmüştür."39

Kur'ân'da iltifatla ilgili birçok örnek vardır. Ancak burada bir iki örnekle iktifâ edilecektir:

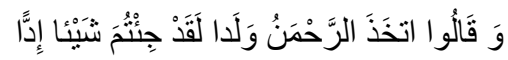

"Rahman çocuk edindi." dediler. Hakikaten çok çirkin bir iddia ortaya attınız." 40

Âyetin başında geçen “ قَالُوا " fiili, gaiplere hitap olarak gelmiştir. Ancak daha

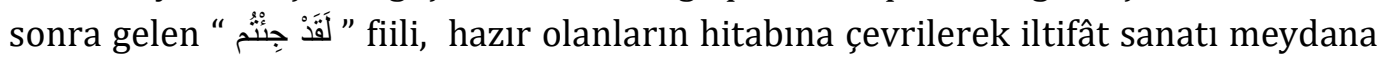
getirilmiştir. Bu sanatın meydana getirilme amacı, Allah Sübhane ve Teâlâ'ya evlat

\section{Hûd11/81; Hicr 15/65.}

İbn Manzûr, "lft", 4052-4053; Muhammed Murtaza el-Hüseynî ez-Zebîdî, "lft", Tâcü'l-'arûs min cevâhiri'l-Kāmûs, (Beyrut: Dârül-Fikr, 1994), 29/126.

Ebü'l-Kāsım Hüseyn b. Muhammed b. el-Mufaddal er-Râgıb İsfahânî, "lft", el-Müfretât fí ġarîbi'lKur'ân, (Mekke: Mektebetu Nezar Mustafa el-Bâz, ts.), 401-402; Zebîdî, "lft", 29/126; Semîn, el'Umdetu'l-ḥuffaz, thk. Muhammed Bâsil Uyunu's-Sud, 4/31; Güneș, Arapça - Türkçe Sözlük, 1070. Zebîdî, "lft", 29/126; Semîn, el-'Umdetu'l-ḥuffaz, thk. Muhammed Bâsil Uyunu's-Sud, 4/31; Güneș, Arapça - Türkçe Sözlük, 1070.

38 Zemahșerî, el-Keșşâf, thk. Adil Ahmed Abdulmevcud - Ali Muhammed Mu'avid, I/119; İsmâil Durmuş, "İltifât", TDV İslâm Ansiklopedisi, (Erişim 19 Mayıs 2020).

39 Ebû'l-Feth Ziyâüddîn Nasrullâh b. Muhammed b. Muhammed eş-Șeybânî el-Cezerî, el-Meselü’ssâ'ir fî edebi'l-kâtib veşs-şấir, thk. Ahmed el-Hufî - Bedevî Tabâne, (Kahire: Dârü Nahdâ, ts.), 2/167-186. 
isnat edenlerin, ne kadar kötü bir davranıșta bulunduklarını gıyaben değil yüzlerine vura vura ifade etmektir. ${ }^{41}$

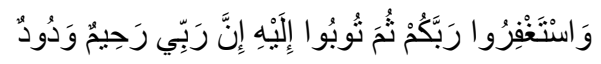

"Rabbinizden bağışlanmayı dileyiniz, sonra O'na tövbe ediniz. Muhakkak ki Rabbimin merhameti ve sevgisi boldur." 42 dedi.

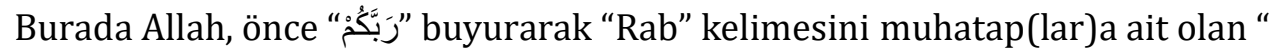
" zamirine izafe ederken, arkasında gelen " رَبِْي " tamlamasında bulunan ve ikinci olan "Rab" kelimesini ise mütekellime ait olan "ي "zamirine izafe etmiştir. Böylece burada muhataptan mütekellime iltifât sanatı meydana gelmiştir. Burada iltifat sanatının meydana gelmesi, Allah'ın rahmetinin çok olduğu/büyük olduğu ve 0 kullarına iyilik ve güzellik yapmada, aşırı bir sevgiyle birine beslenen ve sevgilisine yaptığından daha fazlasını yapmakta olduğunu göstermek içindir. ${ }^{43}$

Necm sûresinde bulunan şu âyette de hitaptan gâibe iltifat vardır:

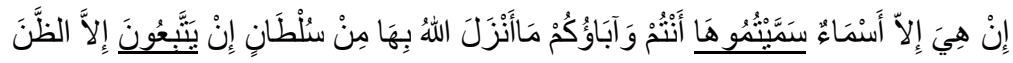

"Onlar, ancak sizin ve babalarınızın isimlendirdiğinizden başka bir şey değildir. Allah buna dair herhangi bir delil de indirmemiștir. Onlar ancak zanna uyuyorlar." 44

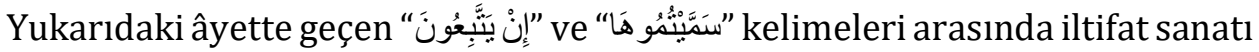
vardır. Zira önceki kelime hitap şeklinde gelmişken, ikinci kelime gaip olarak gelmiştir. Yani hitaptan gaibe iltifat sanatı meydana gelmiştir. ${ }^{45}$ Zira yapmış oldukları çirkinlik ve yanlışlık kendilerinden yüz çevrilip önem vermemeyi gerektirmektedir. ${ }^{46}$

\section{1. 3. Te'kîd}

Te’kîd kelimesi lügatte, "sağlam hale getirmek, güçlendirmek, pekiştirmek" gibi anlamlara gelmektedir. ${ }^{47}$ Bir söz veya kelimeyi pekiștirmeli olarak ifade etmek, Arap dili ve belâgatınin köklü üslûplarından olup en eski gramer eserlerinde de te'kîd ve tevkîd terimleri olarak yer almıştır.48 Belâgatte te'kîdin faydası, sözün, dinleyici veya muhatabın zihnine yerleşmesini, açık seçik anlaşılmasını sağlamaktır. Çeşitli te'kîd edatları ve zait harflerle yapılan pekişmeler mef ûl-i mutlak, hal, temyiz, terdîd, tekrâr, istifhâm, özellikle her türlü ıtnâb üslûbu, haberin te’kîdi ve yemin gibi me’âni

Bk. Herarî, Hadâik, thk. Hâșem Muhammed Ali b. Hüseyin Mehdî, 17/242.

Hud 11/90.

Zemahșerî, el-Keșşâf, thk. Adil Ahmed Abdulmevcud - Ali Muhammed Mu'avid, 3/229.

Necm 53/23.

Sâbunî, Safvetu't-tefâsîr, 3/280; Herarî, Hadâik, thk. Hâșem Muhammed Ali b. Hüseyin Mehdî, 28/157; Selâme, el-I'câzzü'l-belâgī fi'l-Kur'ân, 328.

Herarî, Hadâik, thk. Hâşem Muhammed Ali b. Hüseyin Mehdî, 28/157.

47 Ebû Abdirrahmân el-Halîl b. Ahmed b. Amr b. Temîm Ferâhidî. "ekd", Kitabu'l-'Ayn, thk. Abdulhamîd Hindavî. (Beyrut: Dârü'l-Kütübü'l-c'Illmiyye, 1424/2003), 1/77; es-Seyyid eş-Șerif Ali b. Muhammed Cürcânî, Mu'cemu't-ta'rîfât, thk. Muhammed Sıddık el-Minşâvî, (Kahire: Dârü'lFażile, ts.), 45; İsfahânî, "vkd", 689.

48 Bk. Ferâhidî, "ekd", 1/77; Cürcânî, Mu'cemu't-ta'rîfât, thk. Muhammed Sıddık el-Minșâvî, 45; İsfahânî, "vkd", 689. 
ilminin kapsamına giren belli başlı konulardır. Ancak çalışmanın hacmini de dikkate alarak fazla detaya girilmeyecektir. ${ }^{49}$

Me âni ilminde, muhatabın sözü inkâr etmesini önlemek, ifadenin mecazî anlama hamledilmesine engel olmak, muhatabın şüphesini gidermek, onu uyarmak, sözün zihinde iyice yerleşmesini ve tam anlaşılmasını sağlamak, anlatıma abartı ve azamet kazandırmak, kelamın umumiliğini veya hususiliğini belirlemek gibi amaçlar için te'kîde müracaat edilir. ${ }^{50}$

Kur'ân'da, te'ekid sanatının birçok çeşidine rastlamak mümkündür. Ancak burada bir iki örnekle yetinilecektir:

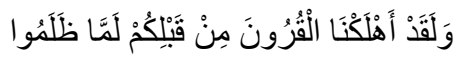

"Sizden önceki nice nesilleri, zülüm ettiklerinden gerçekten helak ettik."51

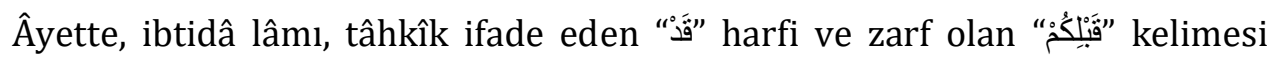
üzerine "مِنِ" harfinin getirilmesi gibi üç yerde te'kîd vardır. Cümlenin te'kidsiz anlamı şöyledir: "Önceki nesilleri, zülüm ettiklerinden helak ettik.” Burada te'kid sanatının kullanılmasındaki amaç, sözü güçlendirmek, pekiştirmek ve muhataba güçlü bir mesaj vermektir.

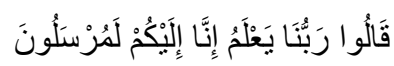

"Dediler ki, hiç şüphesiz Rabbimiz, size gönderildiğimizi çok iyi biliyor." 52

Bu âyette de dört yerde te'kîd mevcuttur; kasem (yemin) mesabesinde olan

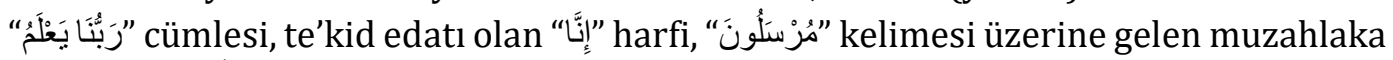

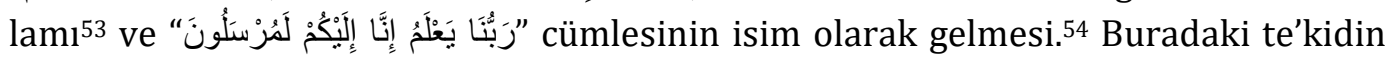
getirilmesi ise elçilerin kendilerini muhataplarına inandırmak, kabullendirmek ve ikna etmek içindir.

Necm sûresinde bir yerde te'kîdin olduğuna müşahede edilmiştir:

إِنْ هُوَ إِلاًَ وَخْيُ يُحَى

49 Konu hakkında detaylı bilgi için bk. Ebû Muhammed Bahâüddîn Abdullah b. Abdurrahmân b. Abdillâh b. Âkîl, Şerhu İbn-i 'Akîl, (Kahire: Dârü't-Turâs, 1980), 271-277; Akkâvî, Mu'cemu'lmufașsal, thk. Ahmed Şemsüddîn, 271; Meydânî, el-Belâġatu'l-'Arabiyye, 2/106-109; Durmuș, "Tekit", TDV İslâm Ansiklopedisi, (Erişim 15 Mayıs 2020). Bk. Akkâvî, Mu'cemu'l-mufașșal, thk. Ahmed Șemsüddîn, 271.

Yunus 10/13.

Yâsin 36/16.

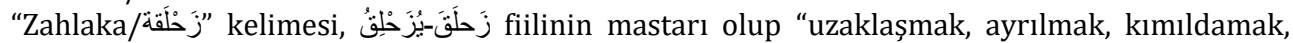
birini yerinden etmek, yerinden kaldırmak" gibi anlamlara gelmektedir (Ferâhidî, "zhlk", 176-

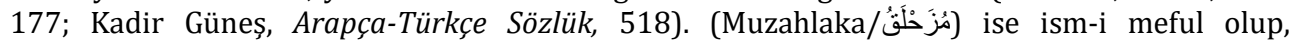
"kaydırılmıș, yerinden edilmiş, yuvarlanmış" anlamını ihtiva etmektedir. Bu lama; mübteda üzerine geldiğinden veya kendisiyle ibtida edildiğinden dolayı "ibtida lam"ı da denilmektedir. İbtidadan maksat, kelamın kedisiyle başlatılması demektir. İbtida lamına "lamu'l muzahlaka" isminin verilmesi, kelamın başından gelmesi gerekirken, inne harfi nedeniyle haber üzerine kaydırılmış, yerinden edilmiş olması hasebiyledir (Ferâhidî, "zhlk", 176-177; Güneş, ArapçaTürkçe Sözlük, 518). 
“0, kendisine indirilmiş vahiyden başka bir şey değildir." 55

Buradaki te'kîd, sıfatla gerçekleştirilmiştir. Zira "وَحَ" kelimesinden hemen sonra gelen "يُحَى" fiili, onun sıfatı olmuştur. Bu ise, cümlede mecazın varlığını ortadan kaldırmaktadır. Yani Hz. Muhammed'in okumuş olduğu şey sözde değil, gerçekten de vahiy mahsulüdür. ${ }^{56}$

\section{1. 4. İstifhâm-ı Tevbîhî}

Öncelikle İstifhâm ve Tevbîh kelimelerinin ne anlama geldikleri çok kısa olarak açıklanacaktır. Sonra da sûredeki örneklere geçilecektir.

İstifhâm kelimesi lügatte, sormak anlamına gelip, kişinin önceden bilmediği bir şeyi sorarak anlamak ve öğrenmek istemesidir. ${ }^{57}$ Kur'ân'da istifhâma örnek olabilecek birçok misâl olmasına karşın şu iki misâlle yetinilecektir:

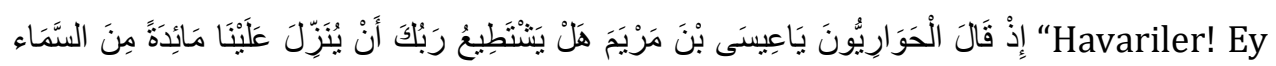
Meryem oğlu İsâ! Rabbin üzerimize bir sofra indirebilir mi? diye sordukları zaman." 58

“Firavun dedi ki! Âlemlerin Rabbi de kimdir?”59

Yukarıda geçen her iki âyette de istifhâm edatı kullanılarak istifhâm sanatı meydana gelmiştir.

İstifhâm birden çok edatla meydana gelmektedir. Söz konusu edatların tümü de istifhâm anlamını ihtiva ettikleri gibi başka anlamları da ihtiva etmektedirler. Bunlar; taaccüp (şaşırmak), emir, nehiy, nefiy, sapıklığa karşı uyarmak, vaîd (tehdit), takrir, inkâr, tehekküm (alay), tahkir (küçümseme), istib`ad (uzak saymak) ve tehvi (korkutmak) gibi anlamlardır. ${ }^{60}$ Konu hakkında geniş bilgi için şu eserlere müracaat edilebilir. 61

Necm 53/4.

Herarî, Hadâik, thk. Hâşem Muhammed Ali b. Hüseyin Mehdî, 28/155-156.

Ferâhîdî, "fhm", 3/344; İsfehânî, "fhm", 499; Matlûb, Mu'cemu'l-muștelehâtt, 1/181; Bedevî, Min belâgati'l-Kur'ân, thk. Dâlyâ Muhammed İbrâhîm, 126.

Mâide 5/112.

Şuarâ 26/23.

Sekkâkî, Miftâhu'l-'ulûm, thk. Abdulhamîd el-Hindâvî, 418-421; Kazvînî, el-İżâh, 112-118; Meydânî, el-Belâgatu'l-'Arabiyye, 1/258; Akkâvî, Mu'cemu'l-mufașșal, thk. Ahmed Șemsüddîn, 234.

61 Sekkâkî, Miftâḥu'l-'ulûm, thk. Abdulhamîd el-Hindâvî, 412; Kazvînî, el-Îżâh, 108-118; Meydânî, elBelâgatu'l-'Arabiyye, 1/258-302; Akkâvî, Mu'cemu'l-mufașșal, thk. Ahmed Şemsüddîn, 234. 
Kınama anlamına gelen62 "Tevbîh" kelimesi ise, belâgat ilminde, bir şeyin kabul edilmediği ifade edilirken, aynı zamanda içinde kınamanın da bulunmasıdır. 63 Şu âyetler buna örnek verilebilir:

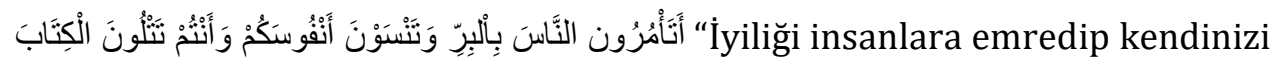
mi unutuyorsunuz? Oysaki kitabı (Tevrat) da okuyorsunuz." 64

"Yonttuğunuz şeylere mi tapıyorsunuz?"65

"Yapamayacağınız şeyleri neden söylüyorsunuz?"66

Yukarıda geçen üç âyette de istifhâm-ı tevbîhî (kınayıcı istifhâm) vardır. İlk iki âyette istifhâm, Arap dilinde en fazla kullanılan "elif" edatı ile yapılırken, son âyette ise "lime" edatı ile yapılmıştır.

Necm sûresinde istifhâm-ı tevbîhî iki yerde gelmiştir: ediyorsunuz." 67

أَفَتُمَارُونَهُ عَلَى مَا يَرَى "Onun (Muhammed'in) gördüklerinden şüphe mi

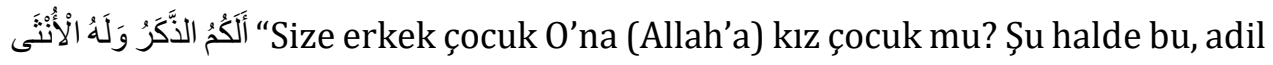
olmayan bir paylaşmadır."68

Buradaki iki âyette de istifham tevbîh anlamında kullanılmıştır.69

\section{1. 5. İtnâb}

İtnâb, insanların aşina olduğu lafızlardan daha fazla lafızla, ancak haşve ve tatvîle $^{70}$ mahal vermeden meramı dile getirmektir. İtnâb kısımları incelendiğinde farklı bakış açılarıyla yapılan değişik taksimleri görmek mümkündür. Bazen itnâbı meydana getiren cümlelerin yapısından hareketle taksim yapılırken, bazen de itnâbın amacından yola çıkılarak taksim yapılmıştır. Bazen de bu iki bakış açısı göz önüne

62 Ferâhîdî, "vbh”, 4/343; Salihu'l-Aliyi's-Salih - Emîne eş-Șeyh Süleymâni'l-Ahmed, "vbh", Mu'cemu'ș-șâfi fi'lügati'l-'Arabîyye, 731; Mecme'u'l-lügati'l-'Arabîyye, el-Mu'cemu'l-vasît, 4. Baskl, (Mısır: Mektebetü'ş-Şürükü'd-Devlîyye, 1425/2004), 1037; Akkâvî, Mu'cemu'l-mufașșal, thk. Ahmed Şemsüddîn, 132. Belâgatu'l-'Arabiyye, 1/274; Akkâvî, Mu'cemu'l-mufașșal, thk. Ahmed Şemsüddîn, 132-133; Matlûb, Mu'cemu'l-muștelehâat, 1/192.

64 Bakara 2/44.

65 âffât $37 / 95$.

66 Saf $61 / 2$.

$67 \quad$ Necm $53 / 12$.

$68 \quad$ Necm 53/15-16.

69 Sâbunî, Safvetu't-tefâsîr, 3/280; Herarî, Hadâik, thk. Hâşem Muhammed Ali b. Hüseyin Mehdî, 28/156; Selâme, el-Íccâzü'l-belâgi fi'l-Kur'ân, 328.

70 Fazla lafzın anlama bir katkısı yoksa ve hangi lafzın fazladan olduğu açık değilse buna gereksiz uzatma manasında tatvîl denirken, fazla lafzın anlama bir katkısı yoksa ve hangi lafzın fazladan olduğu açıksa buna da gereksiz doldurma manasında haşv denir (Akkâvî, Mu'cemu'l-mufașșal, thk. Ahmed Şemsüddîn, 541-543). 
alınarak taksime gidildiği görülmektedir. İtnâbın kullanılmasında, birçok faydanın olduğu söylenmiştir. ${ }^{71}$

İtnâb sanatı ile ilgili örnek çoktur. Ancak çalışmanın hacmi de göz önünde bulundurularak, âyet ve şiirden birer örnek ile iktifa edilecektir:

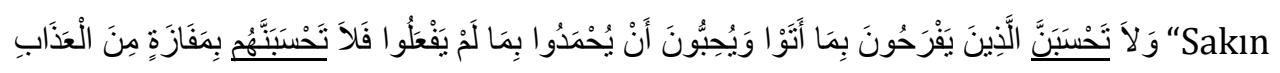

sanma ki yaptıklarından memnun olanlar, yapmadıklarıyla övülmekten hoşlananlar, evet! Asla sanma ki onlar kurtulacaklardır! Onlar için elem verici azap vardır."72

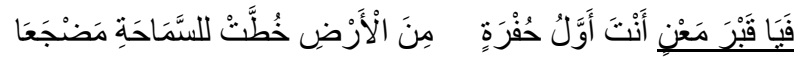

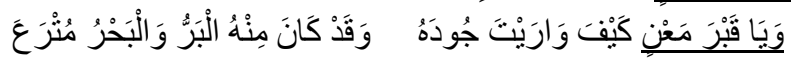

$$
\begin{aligned}
& \text { Sen yerdeki ilk çukursun Ey ma'n'ın kabri! } \\
& \text { Cömertlik için planlanmış bir istirahatgâhsın, } \\
& \text { Onun cömertliğini nasıl örtebildin Ey ma'n'ın kabri! } \\
& \text { Oysa kara da deniz de onun cömertliğiyle doluydu. }{ }^{73}
\end{aligned}
$$

Yukarıdaki âyet ve şiirde altları çizili kelimeler tekrar edildiğinden dolayı itnâb sanatı meydana gelmiştir. ${ }^{74}$

Necm sûresinde de bir yerde itnâb sanatı mevcuttur:

"Sِüüphesiz, Rabbin, yolundan sapanı da iyi bilir; ve 0 , hidâyette olanı da iyi bilir." 75

Âyetteki (أَ أعَلُْم) kelimesi, tekrar edilmiş ve itnâb sanatı oluşmuştur. Bunun faydası ise, olayı muhataba daha güçlü bir şekilde bildirmek olduğu gibi, iki ilmin (bilgi) arasında da farkın olduğunu ifade etmektir. Zira birincisi, delalette, sapkınlıkta olandan bahsederken, ikincisi ise hidâyette, hak yolunda olandan bahsetmektedir. ${ }^{76}$

\section{1. 5. 1. Âm Bir Lafızdan Sonra Has Bir Lafzın Zikredilmesi}

Bu iki kelimenin (âm, has) ne gibi anlamlara gelebileceklerine dair kısa da olsa bir malumat vermekte fayda vardır.

Âm, delâlet ettiği bütün fertleri sınırsız olarak içine alan ve birden çok şeyi ifade eden kelimedir. Diğer bir ifade ile kelime, bir cümle içerisinde birçok şey

71 Sekkâkî, Miftâḥu'l-'ulûm, thk. Abdulhamîd el-Hindâvî, 381; Kazvînî, el-Îżâh, 151-153; Meydânî, elBelâgatu'l-'Arabiyye, 2/62; Akkâvî, Mu'cemu'l-mufașșal, thk. Ahmed Şemsüddîn, 157-158; itnâb kısımları hakkında ayrıca bk. Bulut, Kur'ân-ı Kerim'de İtnab Üslûbu, Uluslararası Sosyal Araștırmalar Dergisi (The Journal of International Social Recearch). Volume 3, Issue 11, Spring 2010, 183-205.

72 Âl-i İmrân 3/188.

73 Meydânî, el-Belâğatu'l-'Arabiyye, 2/65

74 Bk. Kazvînî, el-İżâh, 153; Meydânî, el-Belâgatu'l-'Arabiyye, 2/65; Akkâvî, Mu'cemu'l-mufașșal, thk. Ahmed Şemsüddîn, 169.

$75 \quad$ Necm $53 / 30$.

76 Herarî, Hadâik, thk. Hâşem Muhammed Ali b. Hüseyin Mehdî, 28/157; Selâme, el-Íchâzü'l-belâgi $1 / 328$. 
getiriyorsa ve onların hepsini ifade ediyorsa o kelime âmdır. Has ise, bir tek anlama veya sınırlı sayıdaki fertlere delâlet eden kelimedir.

Âm bir kelimeden sonra has olan bir kelimenin zikredilmesi, belâgat ilminin üç ana bölümünden olan me âni ilminden Ittnâb kısmına dâhil olup faydası, has olan kelimenin önemli veya çok kötü (çirkin) bir anlama delalet edeceğine dair kişiyi uyarmaktır. Bu ise, sanki has, âmın bir çeşidi değil de farklı bir şeymiş gibi bir intiba verecektir. ${ }^{77}$

Kelimenin önemine şu örnek verilebilir:

Namazlara, bilhassa orta namaza devam edin ve huşû içinde Allah'ın huzurunda durun."78

Bu âyette (الصَّلَوَات) kelimesinden sonra (وَالصَّلاةِ الْوِسََى) kelimesi zikredilmesi, ikindi namazının önemli ve faziletli olduğunu göstermektedir.

Kelimenin çok kötü bir şeye delâlet edeceğine örnek ise çalışmanın konusu olan sûrenin şu âyetlerinde görmek mümkündür:

"Arkadaşınız ne sapıtmış ne de eğri yola girmiştir.”79

Âyetteki (غَوَى) fiili, has bir kelimedir. Zira sadece inançta hata yapanlar için kullanılmıştır. (ضَلَّ) fiili ise âm bir kelimedir. Çünkü bu fiil; inanç, söz, fiil ve ahlaktaki hata için kullanılmıştır. Dolayısıyla böyle bir atıfta, has olan bir kelime, âm olan kelimeden sonra zikredilmiştir. Böylece inançtaki hatanın çok kötü ve çirkin bir davranış olduğuna dikkat çekilmiştir. kaçanlar..." 80

"Büyük günahlardan ve çirkin işlerden

Âyette (الْالْثْم) kelimesinden sonra (الْفَرَاحِ) kelimesinin zikredilmesi fuhuşişinin ne kadar kötü ve çirkin olduğunu göstermektedir. Başka bir ifadeyle âyette geçen "ism" kelimesi genel bir kavram olduğundan dolayı "fuhuş" kelimesini de içine almaktadır. Ancak fuhuş fiili o kadar çirkin bir iştir ki, o tekrardan zikredilmiştir. Böylece dikkatler fuhuş ve fahişeliğin çirkinliğine çekilmiş oldu. ${ }^{81}$

\section{1. 5. 2. Has Bir Lafızdan Sonra Âm Bir Lafzın Zikredilmesi}

Has ve âm kelimelerinin tarifine yukarıda kısa bir şekilde değinildiğinden burada tekrar edilmeyecektir.

77 Kazvînî, el-İżạh, 153; Meydânî, el-Belâgatu'l-'Arabiyye, 2/69; Akkâvî, Mu'cemu'l-mufașșal, thk. Ahmed Șemsüddîn, 170.

Bakara $2 / 238$.

Necm 53/2.

Necm 53/32.

Herarî, Hadâik, thk. Hâșem Muhammed Ali b. Hüseyin Mehdî, 28/155-156; konu hakkında geniş bilgi için bk. Akkâvî, Mu'cemu'l-mufașșal, thk. Ahmed Şemsüddîn, 169. 
Has bir lafizdan sonra am bir lafzın gelmesinde ne gibi bir fayda olduğunu ifade etmek gerekirse şunu söylemek mümkündür; has bir lafızdan sonra âm bir lafzın gelmesiyle ta'mim yani genelleștirme meydana gelmekte ve has lafzın önemine dikkat çekilmektedir. ${ }^{22}$ Bunun bir örneği, Yüce Allah, Nuh Peygamberin (a. s.) duasını hikâye ederken görülmektedir:

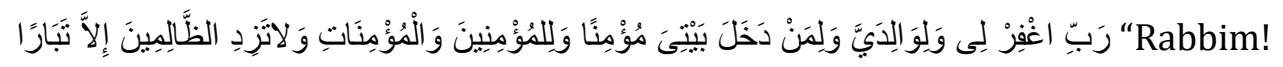
Beni, anne babamı, iman etmiş olarak evime girenleri, inanmış erkek ve kadınları affeyle, zalim kimseleri ise her zaman helak et." 83

Âyette, Nuh (a.s.), ilk önce kendine, sonra anne babasına, daha sonra mümin olarak evine girenlere bağışlama istemiștir. Böylece has bir lafızdan sonra âm getirilmiş ve genelleme yapılmıştır. Zira Nuh (a.s.) da mümin olarak evine girmiş biri

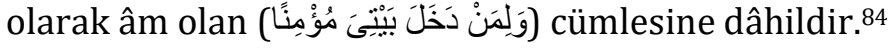

Başka bir örnek de Allah'ın Hz. Muhammed'in iki zevcesine hitabını barındıran aşağıdaki âyette mevcuttur:

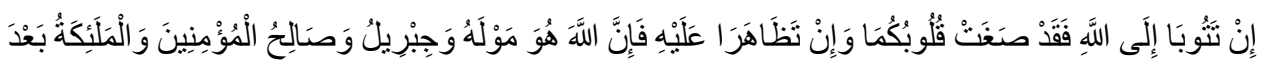

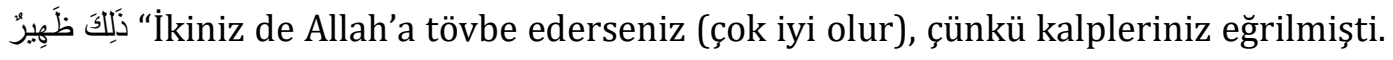
Fakat peygambere karşı bir dayanışma içine girecek olursanız bilin ki herkesten önce Allah onun dostu ve koruyucusudur, sonra da Cebrâil ve salih müminler. Melekler de bunların ardından onun yardımcısıdır." 85

Bazı özelliklerinden dolayı önemli bir Melek olan Cebrâil, âyette önce zikri geçmekte, sonra da meleklerin zikri gelmektedir. Cebrâil de meleklerden olduğu için "Melekler" kavramına dâhildir. Dolayısıyla burada da has bir lafızdan sonra âm bir lafız zikredilmiştir.86

Necm sûresinde, bu tür belâgate bir yerde rastlamak mümkündür.

فَاسنجُدُو المِلَّهِ وَعْبُدُو ا Allah'a secde edin ve ibadet edin.”

Âyette, secdeden sonra ibadet emredilmiștir. Oysa ibadet genel (âm) dir secde ise özeldir ve ibadetin bir alt kısmıdır. Dolayısıyla burada has bir lafızdan sonra âm bir lafız zikredilmiştir. Bu da secdenin önemine delalet etmek içindir. ${ }^{87}$

\section{1. 6. İbhâm}

Belâgat âlimlerine göre "İbhâm", bir sözün, iki veya daha fazla anlama gelebilmesidir. Sekkâki (626/1229) buna "et-Tevcîh" demekte ve şunları ifade etmektedir; "bazı kimseler, onu (İbhâmı), 'iki zıt anlama ihtimali olan kelam' şeklinde

\footnotetext{
82 Bk. Meydânî, el-Belâgatu'l- 'Arabiyye, 2/69; Herarî, Hadâik, thk. Hâșem Muhammed Ali b. Hüseyin Mehdî, 28/155-156.

Nuh 81/28.

Meydânî, el-Belâgatu'l-'Arabiyye, 2/70.

Tahrîm 66/4.

Meydânî, el-Belâgatu'l-'Arabiyye, 2/71.

Bk. Sâbunî, Safvet, 3/281.
} 
tarif etmişlerdir."88 İbhâm bir sözün kullanılmasında şu faydalar mevcuttur; tefhim (yüceltme), tahkir, umumiyet vb. ${ }^{89}$ hatta çağdaş müelliflerden olan Meydânî (öl. 1398/1978), söz konusu faydalarının, belâgatçı olan şahsın zevkine göre sayılamayacak kadar fazla olduğunu söylemiş ve kendisi de on küsur fayda saymıştır. ${ }^{90}$

Çalışmanın konusu olan sûrenin şu âyetlerinde İbhâm sanatı kullanılmıştır:

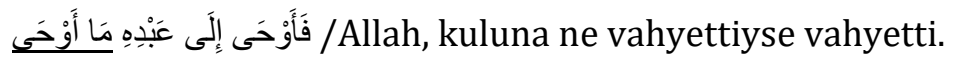

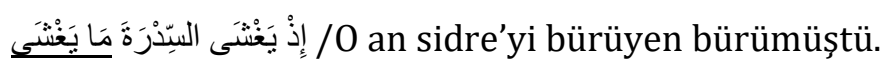

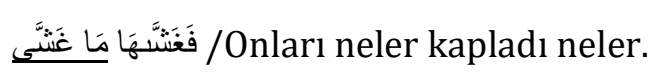

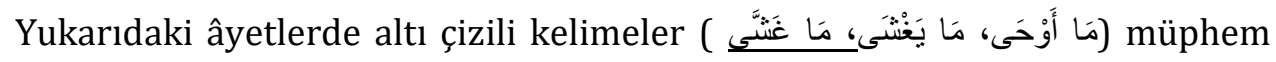
olarak kullanılmıştır. Bunun nedeni ise işin fehâmetini, azametini (yüceliğini) veya dehşetini ifade etmek içindir. ${ }^{91}$

\section{2. Beyân}

Lügatte, "ortaya çıkarmak, açık seçik olmak, açıklamak, anlaşılır hale getirmek" gibi anlamlara gelen beyan kelimesi, terim olarak ise maksadı açı bir şekilde ve değişik yollarla ifade etme usullerini inceleyen ilim dalıdır. ${ }^{92}$ Çalışmanın konusu olan sûrede birden çok beyân sanatı mevcuttur. Söz konsu sanatları şu şekilde açlklamak mümkündür.

\section{2. 1. Teşbih}

Lügatte; "Benzetmek, hikâye etmek" gibi anlamlara gelen teşbih kelimesi tef'îl

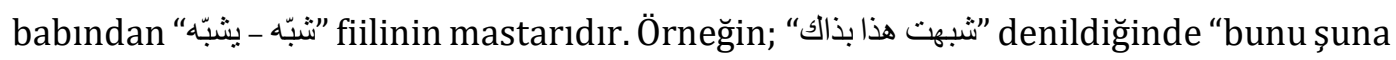
benzettim" demektir. ${ }^{93}$ Burada dikkat edilmesi gereken, söz konusu fiilin benzetme anlamında kullanıldığı zaman cerr harfi olan "bâ" harfiyle beraber gelmesidir. ${ }^{94}$ Istılahta ise; Bir vasıfta aralarında benzerlik bulunan iki şeyden birini diğerine teşbih

88 Sekkâkî, Miftâhu'l-'ulûm, thk. Abdulhamîd el-Hindâvî, 381.

89 İbhâmla ilgili daha fazla bilgi için bk. Sekkâkî, Miftâhu'l'- 'ulûm, thk. Abdulhamîd el-Hindâvî, 381; Kazvînî, el-Î́żâh, 85; Matlûb, Mu'cemu'l-mușțelehâat, 1/37; Akkâvî, Mu'cemu'l-mufașșal, thk. Ahmed Şemsüddîn, 21; Ahmed Ahmed Bedevî, Min belâgati'l-Ḳur'ân, thk. Dâlyâ Muhammed İbrâhîm, (Kahire: Nahdetu Mısır, 1426/2005), 102.

90 Bk. Meydânî, el-Belẩgatu'l- 'Arabiyye, 1/400-409.

91 Bk. Sâbunî, Safvetu't-tefâsîr, 3/280; Herarî, Hadâik, thk. Hâşem Muhammed Ali b. Hüseyin Mehdî, 28/155-156; Selâme, el-İ'câzü'l-belâgì fi'l-Kur'ân, 328.

92 Sekkâkî, Miftâhu'l-'ulûm, thk. Abdulhamîd el-Hindâvî, 381.

92 Bk. Sekkâkî, Miftâhu'l-'ulûm, thk. Abdulhamîd el-Hindâvî, 249; Kazvînî, el-İ̇âh̆, 326; Matlûb, Mu'cemu'l-muștelehật, 1/37; Akkâvî, Mu'cemu'l-mufașșal, thk. Ahmed Şemsüddîn, 21.

93 Ferâhidî, "şbh", 2/204-205; İbn Manzûr, "şbh", İsfahânî, "şbh", 335; es-Seyyid Ahmed el-Hâşimî, el-Cevâhiru'l-Belâgat fi'l-me ânî ve'l-beyân ve'l-bedîc, (Beyrut: Mektebetu'l-Asriyye, 1999), 219. 
edatlarından birinin vasıtasıyla benzetmektir" diye tarif edilmiştir. ${ }^{95}$ Teşbihin kısımları, faydaları ve hakkındaki tüm detaylı bilgi için aşağıdaki teliflere bakılabilir. ${ }^{96}$

Necm sûresinde sadece bir yerde teşbih sanatı tespit edilmiştir:

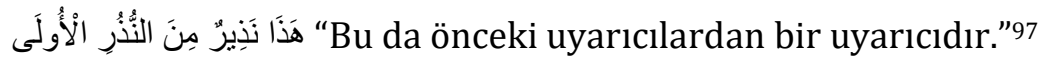

Âyetteki " kelimesinden ya Kur'ân ya da Hz. Muhammed (s.a.v.) kastedilmiş, daha sonra gelen "النُُّّر" kelimesinden de ya önceki kitaplar ya da Hz. Muhammed'den önceki uyarıcı peygamberler kastedilmiştir. Dolayısıyla burada, sonradan gelen uyarıcı, öncekine teşbih edilmiş ve beliğ denilen teşbih sanatı meydana gelmiştir.98

\section{2. 2. İstiâre}

İstiâre kelimesi lügatte, "ödünç talep etmek, herhangi bir şeyi ödünç almak"99 anlamına gelirken, belâgat ilminde ise "bir sözün veya söz öbeğinin, teşbihe mübalağa ve yorum gücü sağlamak için teşbih alakasıyla ve bir karineye dayalı olarak gerçek anlamı dişında kullanılmasıdır"100

Necm sûresinde konuyla alakalı iki örnek mevcuttur:

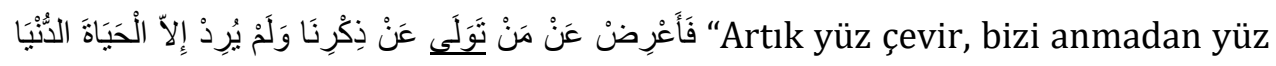
çevirenden ve ancak dünya yaşayışını isteyenden."101 direneni?"102

"Azıcık verip, sonra vermemekte, arkasını getirmemekte

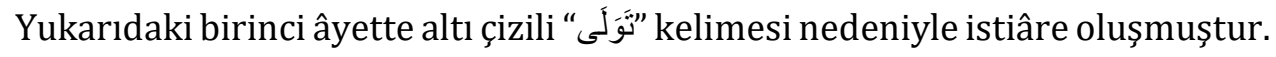
Zira buradaki kelime asılında "yüz çevirme, arka verme, protesto etme gibi" anlamlara gelirken, ${ }^{103}$ bu âyette "iman etmeme, sapıklıkta devam etme" gibi anlamlarda kullanılmıştır.

Aynı şekilde ikinci âyetteki "آَّكَدَ" kelimesiyle istiâre meydana gelmiştir. Çünkü kelimenin asıl anlamı "Yer kabuğunda bulunan sertlik, zorluk, zahmetlik"

95 Kazvînî, el-îzâh șana'ati't-tarasul, (Mısır: Matba'atü'l-Vehbîyye, 1398), 13; Hâşimî, el-Cevâhiru'l-Belâga, 219. Sekkâkî, Miftâhnu'l-'ulûm, thk. Abdulhamîd el-Hindâvî, 439-465; Kazvînî, el-İżâh, 164-172; Meydânî, el-Belâġatu'l-'Arabiyye, 2/162-204; Akkâvî, Mu'cemu'l-mufașșal, thk. Ahmed Şemsüddîn, 322-355; Matlûb, Mu'cemu'l-muștelehật, 2/166-215. Necm 53/56.

98 Sâbunî, Safvetu't-tefâsîr, 3/280; Herarî, Hadâik, thk. Hâşem Muhammed Ali b. Hüseyin Mehdî, 28/188; Selâme, el-íćcâzü'l-Belâgī fi'l-Kur'ân, 328.

99 Ferâhidî, “avr”, 3/253; Meydânî, el-Belâğatu'l-'Arabiyye, 2/229-263; Akkâvî, Mu'cemu'l-mufașșal, thk. Ahmed Şemsüddîn, 88; Ahmed Muhtar Ömer, Mu'cemu luġatu'l-'arabiyyetu'l-ma'asire, (Kahire: Alemu'l-Kütüb, 1429/2008), 1572.

100 İstiare ile ilgili tüm bilgiler için bk. Sekkâkî, Miftâhu'l-'ulûm, thk. Abdulhamîd el-Hindâvî, 477-485; Kazvînî, el-lżâh, 212-225; Meydânî, el-Belâgatu'l-'Arabiyye, 2/229-263; Akkâvî, Mu'cemu'lmufașșal, thk. Ahmed Șemsüddîn, 88-116; Matlûb, Mu'cemu'l-mușțelehâtt, 1/136-174.

101 Necm 53/29.

$102 \quad$ Necm 53/34

103 Ferâhidî, "kda", 4/401; İsfahânî, "kda", 95. 
iken,104 burada "yardım etmeme, verilen şeyi kesme" gibi anlamlarda kullanılmıștır. ${ }^{105}$ Dolayısıyla her iki âyette de istiâre-ı tebeiyye meydana gelmiștir.

\section{2. 3. Kinâye}

Lügatte, kinâye kelimesi يَنَّ- يَكْنُ veya fillerinin mastarı olup "ima etmek, herhangi bir düşünceyi üstü kapalı șekilde ifade etmek” manasında istimal edilir. ${ }^{106}$ Belâgat ilmindeki terim anlamı ise, bir ifadeyi gerçek manasının da anlaşılır bir tarzda olmak üzere, gerçek anlamının dışında kullanmaktır. Kinâyede hakikî ve mecazî anlamların her ikisinin de kastedilmesi mümkündür. Fakat ana gaye, gerçek anlamdan ziyade, mecaz anlamının kastedilmesidir. Diğer taraftan gerçek anlamın kastedilmesine bir mani de bulunmamaktadır. ${ }^{107}$ Kinâye ile ilgili detaylı bilgi için aşağıda verilen eserlere müracaat edilebilir. ${ }^{108}$

Necm sûresinin sadece bir âyetinde Kinâye sanatı gelmiştir:

“ 'Doğrusu, güldüren ve ağlatan, O'dur (Allah’tır).”

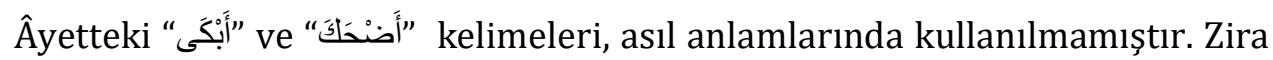
bu kelimelerden kasıt "الحزن" ve "الفرح" gibi kelimelerin ifade ettiği anlamlardır. Dolayısıyla âyetin anlamı, "Doğrusu, sevindiren ve hüzünlendiren O'dur" şeklinde olacaktır. ${ }^{109}$

\section{3. Bedî̀}

Bedî‘ kelimesi lügatte, ilk olan anlamına geldiği gibi, hem eşsiz ve benzersiz olan bir şeyi icat eden, hem de icat edilen bu eşsiz şey anlamlarına gelmektedir. Terim olarak ise muktezâ'yı hâle uygun fasih sözü nasıl güzelleştireceğimizi öğreten ilim dalıdır.110 Sûrede birkaç bedî‘ sanatı mevcuttur ve o sanatları, aşağıdaki gibi izah edilebilmektedir.

104 Ferâhidî, "kda", 4/16; İsfahânî, "kda", 551.

105 Sâbunî, Safvetu't-tefâsîr, 3/280; Herarî, Hadâik, thk. Hâşem Muhammed Ali b. Hüseyin Mehdî, 28/188.

106 Ferâhidî, "kna", 4/53; İbn Manzûr, "kna”, 3944; Cürcânî, Mu'cemut-Ta'rîfât, thk. Muhammed Sıddık el-Minşâvî, 157; Ebû Hasan Ali b. İsmâîl b. Sîde, el-Muḥkem ve'l-muhîțu'l-a'zâm, thk. Muhammed Ali en-Necâr, (Ma'hedu'l-Mahțuțaț, 1393/1973), 7/84; Zerkeşî, el-Burhân, thk. Yusuf Abdurrahman, 2/301; Süyûtî, el-İtkān, 516; Subhî Salih, Mebâḥis fí 'ulumi'l-Ḳur'ân, 10. Baskı, (Beyrut: Dârü'l-'ilim li'l-Melâyyin, 1977), 329-330.

107 Kazvînî, el-îżâh, 241-242; Şerefüddîn el-Hüseyin b. Abdullah b. Muhammed et-Tîbî, et-Tibyân fí 'Illmi'l-Me ânî ve'l-Beyân, thk. Abdüssettar Hüseyin Zemmût (Beyrut: Dârü'l-Cîl, 1996), 406; Zerkeşî, el-Burhân, thk. Yusuf Abdurrahman vd., 2/302; Süyûtî, el-ítkān, 516-518; Emil Bedic Yakub, el-Mu'cemu'l-mufassal fi'l-Lügati ve'l-edeb, (Beyrut: Dârü'l-'Illim li'l-Melâyyin, ts.), 1028. Sekkâkî, Miftâhu'l-'ulûm, thk. Abdulhamîd el-Hindâvî, 512-521; Kazvînî, el-İżạh, 241-251; Meydânî, el-Belâgatu'l-'Arabiyye, 2/133-152; Akkâvî, Mu'cemu'l-mufașșal, thk. Ahmed Şemsüddîn, 628-629; Matlûb, Mu'cemu'l-muștelehât, 3/154-165.

109 Sâbunî, Safvet, 3/280; Herarî, Hadâik, thk. Hâşem Muhammed Ali b. Hüseyin Mehdî, 28/188; Selâme, el-İccâzü'l-belâgì fi'l-Kur'ân, 328.

110 Sekkâkî, Miftâhu'l-'ulûm, thk. Abdulhamîd el-Hindâvî, 532; Kazvînî, el-İżâh, 255; Meydânî, elBelâgatu'l-'Arabiyye, 2/241; Akkâvî, Mu'cemu'l-mufașșal, thk. Ahmed Şemsüddîn, 596; Matlûb, Mu'cemu'l-muștelehâat, 3/104 


\section{3. 1. Tıbâk}

Tıbâk sanatına mutabakat, tatbik, tezat (تضاد) ve tekâfu' (تكافؤ) gibi isimler de verilmiştir. Lügatte uygunluk anlamına gelen tıbâk, terim olarak, anlam bakımından aralarında zıtlık bulunan kelimelerin bir ibarede kullanılmasıdır.111 Gece-gündüz, siyah-beyaz, sert-yumuşak, uzun-kısa, güzel-çirkin, aç-tok, doğu-batı, adil-zalim gibi birbirine zıt kelimeleri bir ibarede toplamak böyledir. Tıbâk sanatı, hem şiirde hem de nesirde meydana gelebilmektedir. Diğer taraftan tıbâk, kelimenin isim, fiil ya da harf olmasına göre değişik şekillerde gelir. ${ }^{112}$

Çalışmanın konusu olan sûrenin şu âyetlerinde bulunan altı çizili kelimler arasında tıbâk sanatı vardır:113

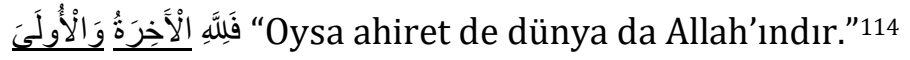

هüphesiz senin Rabbin, yolundan sapanı daha iyi bilir. 0, hidâyete ereni de daha iyi bilir."115 direneni?"116

"Azıcık verip, sonra vermemekte, arkasını getirmemekte

“Doğrusu, güldüren ve ağlatan, O'dur (Allah'tır).”117

"Hiç şüphesiz, öldüren ve tekrar dirilten O'dur. "118 O'dur."119

"Gerçekten, çiftleri, erkek ve dişiyi yaratan da

"Simdi siz gaflet içinde eğlenerek bu söze mi (Kur'ân'a mı) șaşıyorsunuz, gülüyorsunuz da ağlamıyorsunuz?"120

\section{3. 2. Cinas}

Cinas'a, tecnîs, tecânüs, mücânese isimleri de verilir. Manaları farklı, söyleyiş ya da yazılışları aynı veya benzer iki lafzın bir arada kullanılmasıdır. Bu tür sanata bu şekildeki bir ismin verilmesinin nedeni ise her iki lafza ait harflerin aynı cinsten olmasıdır. Belâgat ilmi ile ilgili eserlerde, değişik yönlerden tasnife tabi tutulan cinas,

111 Sekkâkî, Miftâhu'l-'ulûm, thk. Abdulhamîd el-Hindâvî, 527; Kazvînî, el-Îżâh, 255; Meydânî, elBelâgatu'l-'Arabiyye, 2/377; Akkâvî, Mu'cemu'l-mufașșal, thk. Ahmed Şemsüddîn, 596; Matlûb, Mu'cemu'l-musțelehât, 3/66.

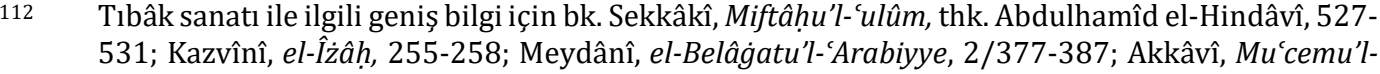
mufașșal, thk. Ahmed Șemsüddîn, 596-598; Matlûb, Mu'cemu'l-muștelehâtt, 3/66-67.

113 Sâbunî, Safvet, 3/280; Herarî, Hadâik, thk. Hâșem Muhammed Ali b. Hüseyin Mehdî, 28/188; Selâme, el-I'ćâzü'l-belâgì fi'l-Kur'ân, 328.

114 Necm 53/25.

$115 \quad$ Necm $53 / 30$

$116 \quad$ Necm 53/34.

$117 \quad$ Necm $53 / 43$

$118 \quad$ Necm $53 / 44$

$119 \quad$ Necm $53 / 45$

$120 \quad$ Necm $53 / 59,60$. 
genellikle cinâs-ı tâm ve cinâs-ı nâkıs şeklinde iki bölüme ayrılmıştır. Daha sonra her iki bölüm de farklı bölüm ve kısımlara ayrılmıștır. Burada bunların detayına girmektense, çalışmada gelen her bölüm kısa bir şekilde tarif edilecektir. Cinas tabiî olarak ortaya çıktığında, yapısındaki musiki ahengiyle birlikte dile hafiflik, söze de güzellik katar, kulağa hoş gelir ve kalplerdeki tesir daha çok olur. ${ }^{121}$ Ancak tabiî değil de zorlamayla yapılan cinas sanat olmaktan ziyade kulaklar için bir yük ve ağırlık halini alır. Nitekim bu tür cinas, âlimlerin birçoğu tarafından tenkit edilmiş ve kabul görmemiştir. 122

\section{3. 2. 1. Cinâs-1 Mustevfâ (جناس المستوفى)}

Mustevfâ cinas, tâm cinasın bir alt bölümü olup, benzer kelimelerden biri isim diğeri de fiil olduğu zaman meydana gelmektedir. Buna cinâs-ı mugayir de

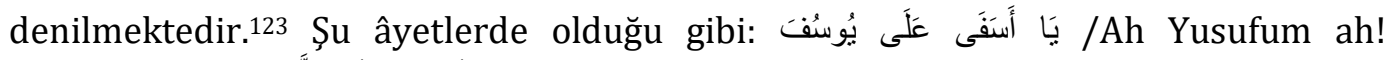

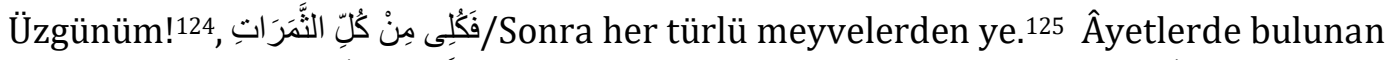

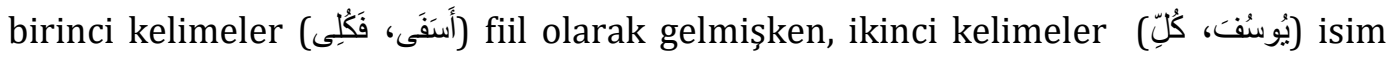
olarak gelmiştir. ${ }^{126}$

Başka bir örnek de Ebû Temmâm'ın şu şiirinde gelmiştir:

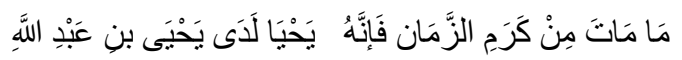

Zamanın cömertliklerinden her ne ölmüş ise

Aslında o, Yahyâ b. Abdullah'ın katında yaşamaktadır.

Şiirde kullanılan "يَحَيْيَى" kelimesinin ilki fiil, ikincisi ise isimdir.127

Necm sûresinde, cinasın bu türüne örnek birkaç yerde gelmiştir.

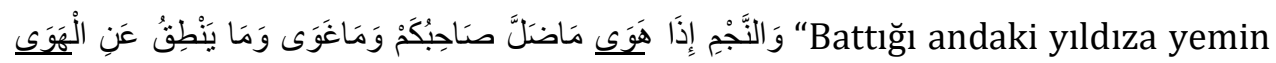
olsun ki! Sizin arkadaşınız (Hz. Muhammed), sapıtmamış ve doğru yoldan da çlkmamıştır. O, kendi hevâsından (nefsinin arzusu) da konuşmuyor."128

Yukarıdaki âyette altı çizili "هَوَى" kelimeleri arasında mustevfâ cinas sanatı vardır. Zira kelimelerden ilki fiil, diğeri ise isim olarak gelmiştir. Aynı zamanda

\footnotetext{
121 Bk. Sekkâkî Miftâhu'l-'ulûm, thk. Abdulhamîd el-Hindâvî, 533; Muhammed Ali et-Tehânevî, Keşşâfu ișțilahati'l-fununi ve'l-'ulûmi, thk. Ali Dahrüc, (Beyrut: Mektebetü Lübnan Nâşirun, 1997), 1/648; Ali Bulut, Belâgat (Meânî-Beyân-Bedî), 3. Baskı, (İstanbul: İFAV. 2015), 331-332. Detaylı bilgi için bk. Ebû Bekir Abdulkâhir b. Abdurrahmân b. Muhammed el-Cürcânî en-Nahvî, Esrâru'l-belag̉ā, thk. Mahmûd Muhammed Şâkir, (Cidde: Dârü'l-Medenî, ts.), 41-46. Sekkâkî, Miftâhu'l-‘ulûm, thk. Abdulhamîd el-Hindâvî, 533; Tehânevî, Keșşâfu ișțilahati'l-fununi ve'l-'ulûmi, thk. Ali Dahrüc, 1/648; Meydânî, el-Belâgatu'l-'Arabiyye, 2/486-487; Bulut, Belâgat, 332.

124 Yusuf $12 / 84$

125 Nahl 16/69.

126 Akkâvî, Mu'cemu'l-mufașșal, 517-518; Herarî, Hadâik, thk. Hâșem Muhammed Ali b. Hüseyin Mehdî, 28/155.

127 Bk. Habîb b. Evs b. Hâris Ebû Tammâm et-Tâî, Divânu Ebî Tammâm bi-Şerhi'l-Hatîb et-Tebrîzî, nşr. Muhammed Abduh Azzam, (Kahire: Dârü'l-Me'ârif, ts.), 3/347; Akkâvî, Mu'cemu'l-mufașșal, thk. Ahmed Şemsüddîn, 489. 
harfleri aynı olduğu gibi; harflerin sıraları, sayıları ve heyetleri de aynıdır. Ancak iki kelimenin anlamı farklıdır. Birinci kelime "batmak, çökmek, inmek, devrilmek" gibi anlamlara gelirken, ikinci kelime ise "nefsin isteği, arzusu, talebi" gibi anlamlara gelmektedir. ${ }^{129}$

"Bu putlar sizin ve atalarınızın uydurduğu boş isimlerden başka bir şey değildir."130

Yukarıdaki âyette altı çizili kelimeler arasında mugayir cinas mevcuttur.

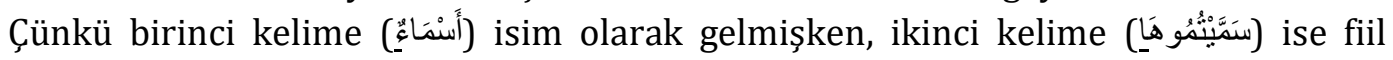
şeklinde gelmiştir. ${ }^{131}$

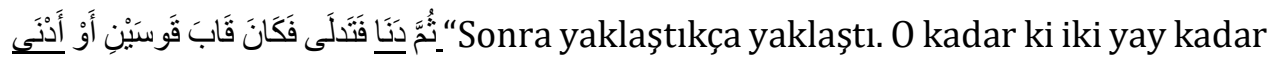
hatta daha yakın oldu." 132

Âyetteki altı çizili (دَنَا، أَدْنَى) kelimeler, aynı türden olmalarından ve birincisi fiil, ikincisi isim (ism-i tâfdil) olmalarından aralarında cinâs-ı müstevfâ meydana gelmiștir. ${ }^{133}$

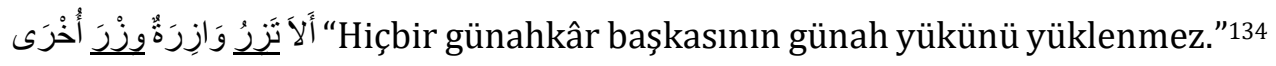

Bu âyette de altı çizili kelimler arasında cinâs-ı müstevfâ mevcuttur.135

\section{3. 2. 2. Cinâs-ı İștikâk}

Cinâs-ı iştikâk, kök harfleri itibariyle iki kelimenin aynı olmasıdır. Bu tür

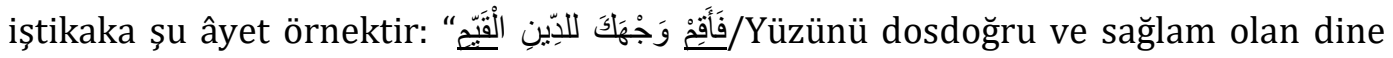
çevir."136

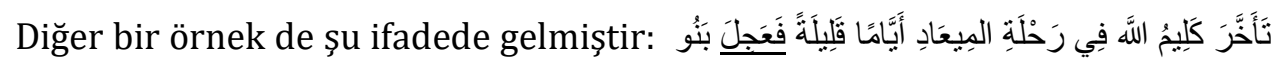

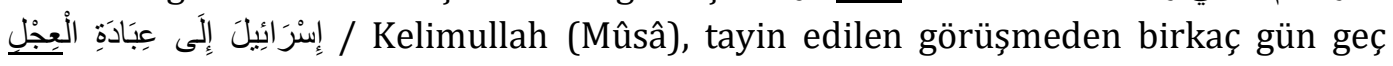
dönmüştü ve İsrailoğulları buzağıya tapınmak için acele ettiler. ${ }^{137}$

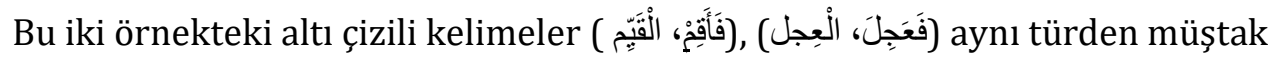
olduklarından dolayı aralarında cinâs-ı iştikâk meydana gelmiştir. Ancak bazı âlimler

\footnotetext{
129 Ferâhidî. "hva", 333-334; Zemaherî, el-Keșşâff, thk. Adil Ahmed Abdulmevcud - Ali Muhammed Mu'avid, 5/634-635; Sûyütî, ed-Dürrü'l-menŝ̂r fi't-tefsîri bi'l-me’sûr, thk. Abdullah b. Abdulmuhsin et-Türkî, (Kahire: Merkezu Hecer, 1424/2003), 14/7-10; Ebû'l-Kāsım el-Hüseyin b. Muhammed er-Râğib el-İsfehânî, el-Müfredât fí ġarîbi'l-Kur'ân, nşr. Mektebetü Nezâr Mustafâ elBâz, ts. 712-713; Herarî, Hadâik, thk. Hâşem Muhammed Ali b. Hüseyin Mehdî, 28/149, 155.

$130 \quad$ Necm $53 / 23$

131 Herarî, Hadâik, thk. Hâşem Muhammed Ali b. Hüseyin Mehdî, 28/157.

132 Necm 53/8-9.

133 Herarî, Hadâik, thk. Hâșem Muhammed Ali b. Hüseyin Mehdî, 28/156; Selâme, el-Íćcâzü'l-belâgi $1 / 328$.

$134 \quad$ Necm $53 / 38$

135 Herarî, Hadâik, thk. Hâşem Muhammed Ali b. Hüseyin Mehdî, 28/188; Selâme, el-İ'câzü'l-belâgī, $1 / 328$.

136 Rum 30/43.

137 Sekkâkî, Miftâhnu'l-'ulûm, thk. Abdulhamîd el-Hindâvî, 534; Meydânî, el-Belâgatu'l-'Arabiyye, 2/498; Akkâvî, Mu'cemu'l-mufașșal, thk. Ahmed Şemsüddîn, 489.
} 
söz konusu bu iştikakı, iştikakın kısımlarından değil de iştikaka lâhik ${ }^{138}$ olan kısmından saymıștır. Bu tür iștikakın diğer bir ismi de iștikâk-ı mutlâktır. ${ }^{139}$ Fakat İbn Hücce el-Hamevî (öl. 626/1229), iki türün arasında farkın olduğunu şu ifadeleriyle dile getirmiștir: "Cinâs-ı mutlâk, cinâs-ı iștikâka fazlaca benzediğinden sanki aynı imiş gibi görülebilir. Yalnız hiç de aynı değildirler. Zira şu âyetleri ele aldığımızda iki iştikak arasındaki fark daha net bir şekilde görülecektir: '

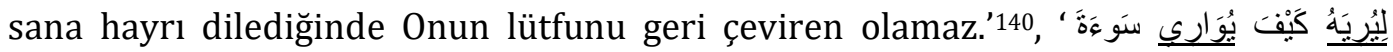
أَخِيه Kardeşinin cesedini nasıl örtecek diye ona göstersin'.141 Yukarıdaki âyetlerde altı

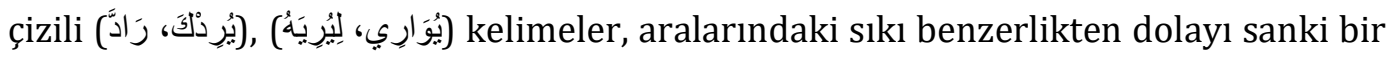
türden kelimeler olduğu intibaı verebilir. Ancak kelimler tetkik edildiğinde, farklı türden oldukları anlaşılmaktadır. Oysa cinâs-ı iştikâkta kelimelerin aynı türden (kökten) olmaları gerekmektedir." 142

Çalışma konusu olan sûrede bu türden iki örnek mevuttur:

Ahiret gününe inanmayanlar, melekleri dişi olarak isimlendiriyorlar." 143

Âyetteki altı çizili kelimeler arasında cinâs-ı iştikâk vardır.

Ve insan için kendi çabasından başka bir şey yoktur. Şüphesiz kendi çabası da ileride görülecektir.”144

Yine bu âyette altı çizili kelimeler (سَعْيَهُ، مَا سَعَىى) arasında cinâs-ı iştikâk vardır.

"Yaklaşmakta olan (kiyamet) iyice yaklaştı. Onu, Allah'tan başkası ortaya çıkaramaz".145

Âyetin hemen başında gelen “"الَّآزفَفُهُ" velimeleri arasında cinâs-ı iştikâk vardır. ${ }^{146}$

Yukarıda verilen yedi örnekten dördü cinâs-ı mustevfâ, üçü de cinâs-ı iştikâka ait olduğu bazı eserlerde geçmektedir. Ancak biraz dikkat edildiğinde, aslında her iki kısım örneğin de hem cinâs-ı mustevfâ hem de cinâs-ı iştikâk kısmında birleștikleri görülecektir.

Cinas-ı lahik, cinası meydana getiren kelimelerde harflerin türlerinin farklı olup, mahreçlerinin de birbirinden uzak olmasıdır. Bu farklılık ya bir harftedir ya da birden fazla harftedir (bk. Kazvînî, el-Î́zâh, 291-292).

Sekkâkî, Miftâhu'l-'ulûm, thk. Abdulhamîd el-Hindâvî, 534; Meydânî, el-Belâgatu'l-'Arabiyye, 2/498; Akkâvî, Mu'cemu'l-mufașșal, thk. Ahmed Șemsüddîn, 489.

Yunus 10/107.

Mâide 5/31.

Akkâvî, Mu'cemu'l-mufașșal, thk. Ahmed SSemsüddîn, 489; ayrıca bk. Sekkâkî, Miftâḥu'l-'ulûm, thk. Abdulhamîd el-Hindâvî, 535; Kazvînî, el-İżâh, 293; Meydânî, el-Belâgatu'l-'Arabiyye, 2/498.

Necm 53/27.

Necm 53/39-40.

Necm 53/57-57.

Herarî, Hadâik, thk. Hâşem Muhammed Ali b. Hüseyin Mehdî, 28/157; Selâme, el-Íçâzü'l-belâgi í, $1 / 328$. 


\section{3. 2. 3. Cinâs-ı Mümâsil}

Cinas-ı oluşturan iki kelimenin tür bakımından aynı olmasıdır. Yani fiil, isim ya da harf olma cihetinde müşterek olmasıdır.147 Nitekim Teftâzânî ( öl. 792/1390), "bu tür cinasa mümâsil denilmesi, Mütekellimlerin de ıstılahatında olduğu gibi, kelimelerin aynı neviden yani benzer olmasından dolayıdır"148 derken, İbn Reşîk (öl. 456/1064) ise, "lafızları aynı anlamları farklı" şeklinde tarif etmiştir. ${ }^{149}$ Aşağıdaki âyet ve şiirde bunun örneklerini görmek mümkündür:

"Kiyametin koptuğu gün suçlular (dünyada) bir saatten fazla durmadıklarına yemin ederler."150

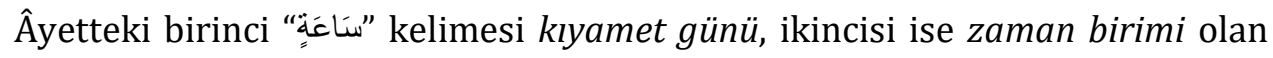
saattir.

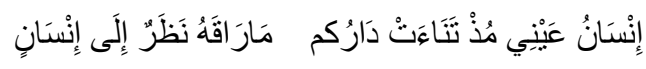

Sizin eviniz uzaklaştığından bu yana, herhangi bir insana bakmak, göz bebeğimi mutlu etmemiştir.

Bu şiirin hemen başında gelen "“إِنََْان” kelimesi göz bebeği, sonunda gelen ise insan manasında kullanılmıştır.

Ele alınan sûrede cinâs-ı mümâsile örnek iki yerde geçmektedir:

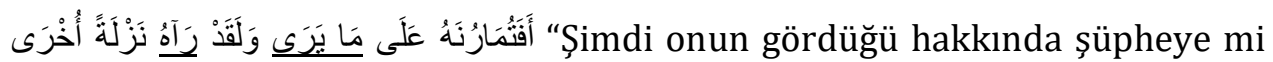
düşüyorsunuz? And olsun ki onu başka bir inişte de görmüştü. "151

Âyette altı çizili kelimler ( مَا يَنَى, رَآهُ ) arasında cinâs-ı mümâsil vardır. Zira her iki kelime de fiil olarak gelmiștir. ${ }^{152}$

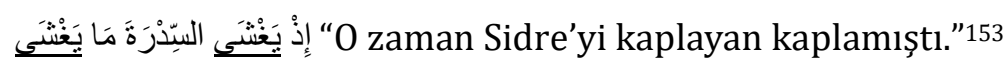

Bu âyette de cinâs-ı mümâsil sanatı vardır. Zira altı çizilen her iki kelime de fiil olarak gelmiştir.

\footnotetext{
147 Sekkâkî, Miftâhu'l-'ulûm, thk. Abdulhamîd el-Hindâvî, 533; Kazvînî, el-Îżâh, 288; Meydânî, elBelâgatu'l-'Arabiyye, 2/498.

148 Kazvînî vd, Şürüḥü't-Telhị̂s, (Beyrut: Dârü'l-Kütübü'l-'İlmiyye, ts.), 4/415; Akkâvî, Mu'cemu'lmufașșal, thk. Ahmed Şemsüddîn, 519.

149 Ebû Ali el-Hasen b. Reşîk el-Ezdî el-Mesîlî el-Kayravânî, el-'Umde fî mehâsini'ş-şi'r ve âdâbih ve naḳdih, thk. Muhammed Muyuddîn Abülhamîd, (Beyrut: Dârü'l-Cîl, 1401/1981), 1/321; Akkâvî, Mu'cemu'l-mufașșal, thk. Ahmed Şemsüddîn, 519.

$150 \quad$ Rum 30/55.

$151 \quad$ Necm 53/12-13

152 Herarî, Hadâik, thk. Hâșem Muhammed Ali b. Hüseyin Mehdî, 28/156; Selâme, el-İcâzü'l-belâgín, $1 / 328$.

$153 \quad$ Necm 53/16
} 


\section{3. 2. 4. Cinâs-ı Nâkıs}

Bu tür cinasa Gayr-ı Tâm cinas da denilmiștir. Bu da iki kelime arasında harflerinin türü, sırası, sayısı, hareke ve heyeti gibi benzerliklerden birisinin olmamasıdır. ${ }^{154}$

Nakıs cinasa şu âyet örnek verilebilir:

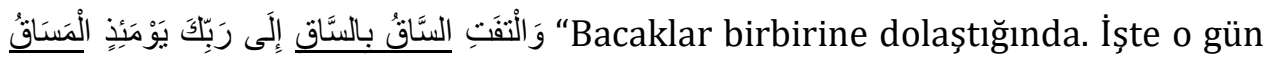
sevk edilen yer, sadece rabbinin huzurudur." 155

Hassân b. Sabit'in (ö. 60/680) şu beyti de konuya örnek olarak vermek mümkündür:

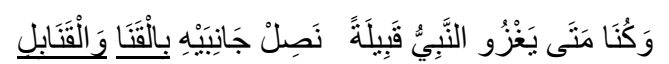

Nebi (Hz. Muhammed), bir kabile ile savaştığında, etrafını mızrak ve insanlarla sarardlk.

Âyet ile şiirdeki altı çizili kelimeler arasında nakıs cinas mevcuttur. Zira her iki örnekte de kelimeler arasında harf eksikliği vardır. ${ }^{156}$

Çalışmanın konusu olan Necm sûresinde nakıs cinas türüne bir örnek bulunmaktadır:

“'Zengin kllan da O’dur. Kanaatkâr eden de.”"157

Âyetteki (أَغْنَ) ve (أَفْنَى) kelimeleri arasında harf farklılığından dolayı nakıs cinas vardır. ${ }^{158}$

\section{3. 2. 5. Cinâs-1 Kalb}

Cinası oluşturan kelimelerin sıralanışının farklı olmasına cinâs-ı kalb ya da tecnis-i kalb denir. Aynı zamanda buna cinâs-ı 'aks adı da verilmiştir. Bu da iki kelimeden birisi tersinden okunduğunda oluşan cinastır. ${ }^{159} \mathrm{Bu}$ tür cinasa ait örnekler Kur'ân-ı Kerîmde oldukça azdır. 160

Cinâs-ı kalb; kalb-i küll, kalb-i ba'z, maklûb-i mücennah ve cinâs-ı müstevî seklinde dörde ayrılır. Kalb-i küll de düzenli (muntazam) kalb ve düzensiz (muavvec)kalb olmak üzere ikiye ayrılır. ${ }^{161}$

\footnotetext{
154 Bk. Sekkâkî, Miftâhu'l'-'ulûm, thk. Abdulhamîd el-Hindâvî, 533; Meydânî, el-Belâgatu'l-'Arabiyye, 2/492.

155 Kiyâme 75/29-30

156 Bk. Sekkâkî, Miftâhu'l-'ulûm, thk. Abdulhamîd el-Hindâvî, 533; Kazvînî, el-lízâhh, 290; Meydânî, elBelâgatu'l-'Arabiyye, 2/494; Akkâvî, Mu'cemu'l-mufașsal, thk. Ahmed Şemsüddîn, 472. Necm 53/48.

Sâbunî, Safvet, 1/328.

Akkâvî, Mu'cemu'l-mufașșal, thk. Ahmed Șemsüddîn, 487. Bulut, Belagât, 342.

Kalb sanatı, çesitleri ve örnekleri için bk. Sekkâkî, Miftâhu'l'-'ulûm, thk. Abdulhamîd el-Hindâvî, 533; Kazvînî, el-İżâh, 241-242; Kazvînî, el-îzâh , 290; M. Kaya Bilgegil, Edebiyat Bilgi ve Teorileri,
} 
Cinâs-ı kalbe örnekler, şu şiir ve ifadelerde görmek mümkündür:

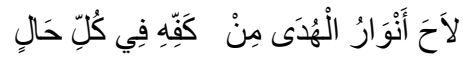

Her durumda onun avucundan hidâyet nuru parladı.

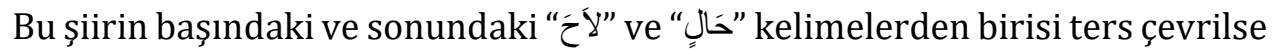
cinâs-ı kalb oluşur.

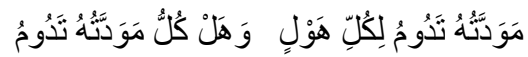

Onun sevgisi her türlü korkuda devam eder.

Herkesin sevgisi her hâlükârda devamlı olabilir mi?

Bu şiirde ise, şiirin iki yarısından birisi tersten okunduğundan diğer yarısının aynisı olur.

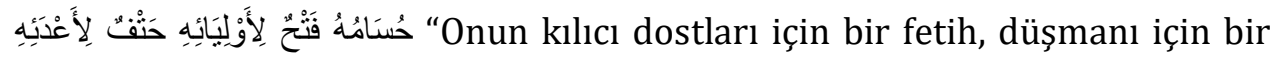
ölümdür."

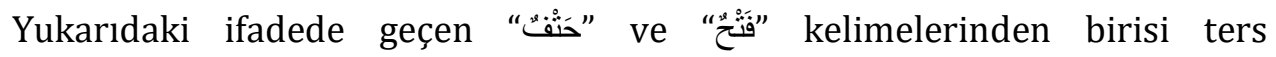
çevrildiğinde, diğerinin aynısı olmaktadır.

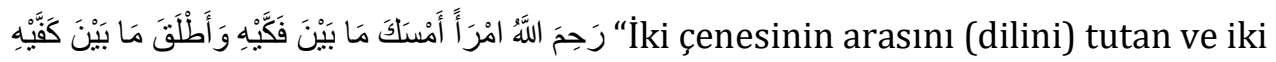
avucunun arasındakini (elindeki) serbest birakana (verene) Allah rahmet etsin."

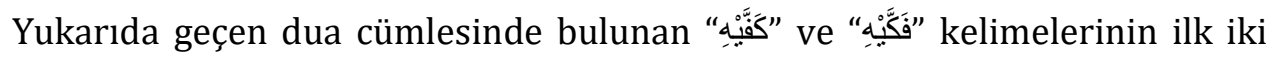
harfleri ters çevrildiğinde anlamları birbirini karşılar. ${ }^{162}$

Konuyla ilgili örnek, Necm sûresin bir âyetinde görülmektedir:

“Sonra yaklaştı ve sarktı.”163

Âyette gelen fiillerin yer değiştirmesiyle cinâs-ı kalb sanatı meydana gelmiştir.

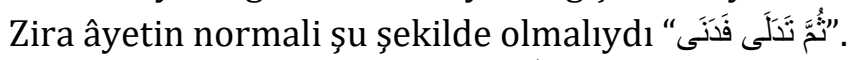

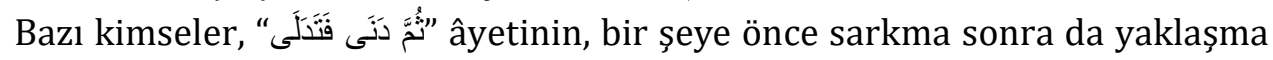
olacağı için, yaklaşma ve sarkma fiillerinin yer değiştirmesiyle "Önce sarktı, sonra yaklaştı" manasına geldiğini söylerken, bazıları ise bu iki fiilin yakınlık anlamında eşit olmaları sebebiyle, âyette böyle geldiğini söylemiștir. ${ }^{164}$

\section{Sonuç} ulaşılmıştır.

Necm sûresi ile ilgili yapılan bu kısa çalışmada aşağıdaki neticelere 2. Baskı, (İstanbul: Enderun Kitabevi, 1989), 330-331; Ahmed Cevdet Paşa, Belagât-ı Osmaniyye, Hazırlayan; Turgut Karabey - Mehmet Atalay, (Ankara: Akçağ Yayınları, 2000), 38; L. Sami Akalın, Edebiyat Terimleri Sözlüğü, 3. Baskı, (İstanbul: Varlık Yayınevi, 1972), 103; Seyit K. Karaalioğlu, Edebiyat Terimleri Kllavuzu, (İstanbul: İnkilap - Aka Kitaevleri, 1975), 181.

164 Abdülkerim Seber, İmam Ebû Mansur Muhammed Mâtürîlînnin "Te'vilâtü'l-Kur'ân" Inda Necm Sûresi Tefsîri: Tercüme - Tahlîl - Mukayese, Bilimname 11. 2006/2, 97-139, 9. 
Yıldız'a yemin edilerek başlanılan sûre, altmış iki âyetten müteşekkil olup bir âyeti hariç Mekke şehrinde nazil olmuş ve Hz. Muhammed'in (s.a.v.) Mekke'de müşriklerin bulunduğu bir ortamda açıktan okuduğu ve içinde tilavet secdesi olan ilk sûredir. İsmini, başında geçen ve cumhurun görüşüne göre yıldız anlamına gelen "Necm" kelimesinden almıştır.

Sûrenin muhtevasını genel itibariyle, tevhid, nübüvvet ve ahiret hayatı gibi konular teşkil etmektedir. Bu bağlamda, Allah'ın kızları oldukları iddia edilen birkaç putların isimleri zikredilmiş ve bu putlara tapan kimseler kendilerinin kız babası olmalarını hazmedemedikleri halde, nasıl olur da Allah'a kız babası yakıştırmayı uygun gördüklerini eleştirel bir üslupla dile getirilmiştir. Sonra Hz. Muhammed'in (s.a.v.) hak peygamber, Kur'ân'ın da vahiy mahsulü olduğu, bir gök cismi olan yıldıza kasemle te'yid edilmiş ve Hz. Muhammed'in (s.a.v.) müşriklerin iddiasının tam tersine hak ve dürüstlük yolundan ayrılmadığı bildirilir. Daha sonra eski ümmetlerin, Peygamberlerinin tebliğine kulak asmamalarından ve iman etmemelerinden dolayı çeşitli afetlerle helak olduklarını, kıyametin yaklaştığı ancak ne zaman vuku bulacağı sadece Allah'ın bilebileceği, müşriklerin Allah'ın kelamı karşısında laubali davranmamaları gibi önemli konular anlatılmıştır.

Sûrenin bir bütün şeklindeki nüzul sebebi ile beraber bazı âyetlerin de müstakil nüzul sebebi mevcuttur. Necm sûresinin, kendisinden önceki Tur ve sonrasındaki Kamer sûreleri ile münasebet ve insicamı, Kur'ân'ın bütünlüğüne uygun bir şekilde tam ve mükemmeldir. Sûre ile bağlantılı olarak öne sürülen garânîk olayının gerçekle bir alakası olmadığı açıktır. Sûrede belâgat sanatının birçok çeşidinin olduğu tespit edilmiştir. Bu sanatların arasında; birçok alt dalı ile birlikte cinas, itnâb, âm-has, te'kîd, ibhâm, istifhâm, iltifât, istiâre, tıbâk, kınâye, teşbih gibi kısımların olduğuna müşahede edilmiştir.

\section{Kaynakça}

Ahmed Cevdet Paşa. Belâgat-ı Osmaniyye. Hazırlayan; Turgut Karabey \& Mehmet Atalay, Ankara: Akçağ Yayınları, 2000.

Akalın, L. Sami. Edebiyat Terimleri Sözlüğü. 3. Baskı, İstanbul: Varlık Yayınevi, 1972.

Akkâvî, İn âm Fevvâl. Mu'cemu'l-mufașșal fí 'ulûmi'l-belâga. Thk. Ahmed Şemsüddîn, Beyrut: Dârü'l-Kütübü'l-'illmiyye, 2. Basım, 1417/1996.

Âlusî, Ebû Senâ Şihâbüddîn Mahmûd b. Abdillâh b. Mahmûd el-Hüseynî. Ruhu'l-Mecânî. Nşr. Mahmûd Şükrî el-Âlusî el-Bağdâdî, 30 Cilt. Beyrut: Dârü İhyai't-Turâsi'l- 'Arabî, ts.

Bedevî, Ahmed Ahmed. Min belâgati'l-Kur'ân. Thk. Dâlyâ Muhammed İbrâhîm, Kahire: Nahdetu Misır, 1426/2005.

Bilgegil, M. Kaya. Edebiyat Bilgi ve Teorileri. İstanbul: Enderun Kitabevi, 2. Basım, 1989.

Bilmen, Ömer Nasuhi. Büyük Tefsir Tarihi ve Tabakât-u'l-müfessirîn. İstanbul: 1973.

Bulut, Ali. Belâgat (Meânî-Beyân-Bedî). İstanbul: İFAV. 3. Basım, 2015.

Bulut, Kur'ân-ı Kerîm'de İtnâb Üslûbu. Uluslararası Sosyal Araștırmalar Dergisi (The Journal of International Social Recearch). Volume 3, Issue 11, Spring 2010.

Cerahoğlu, İsmail. Tefsîr Usulü. Ankara: 1993.

Cerrahoğlu, İsmail. "Garânîk", TDV İslâm Ansiklopedisi, (Erişim 19 Haziran 2020).https://islamansiklopedisi. org.tr/garânîk 
Cürcânî, Ebû Bekir Abdulkâhir b. Abdurrahmân b. Muhammed en-Nahvî. Esrâru'l-belâga. Thk. Mahmûd Muhammed Şâkir, Cidde: Dârü'l-Medenî, ts.

Cürcânî, es-Seyyid eș-Şerif Ali b. Muhammed. Mu'cemu't-ta'rîfâtt. Thk. Muhammed Sıddık elMinșâvî, Kahire: Dârü'l-Fazile, ts.

Demirci, Muhsin. Tefsîr Usulü. İstanbul: İFAV. Yayınları, 23. Basım, 2013.

Derveze, Muhammed İzzet. et-Tefsîrü'l-ḥadîs. 10 Cilt. Kahire: Dârü'l-Ġarbi'l-İ́slâmî, 2000.

Durmuş, "İltifât", TDV İslâm Ansiklopedisi, (Erişim 19 Mayıs 2020). https://islamansiklopedisi. org.tr/iltifat

Durmuş, İsmâil, "Tekit", TDV İslâm Ansiklopedisi, (Erişim 15 Mayıs 2020). https://islamansiklopedisi. org.tr/tekit.

Bardakoğlu, Ali, "Cins", TDV İslâm Ansiklopedisi, (Erişim 21 Eylül 2020). https://islamansiklopedisi.org. tr/cins\#2-fikih

Ebû Hayyân, Muhmmed b. Yusuf el-Endelûsî. el-Bahru'l-muhịt. Thk. Adil Ahmed Abdulmevcud \& Ali Muhammed Mu'avid, 8 Cilt. Beyrut: Dârü'l-Kütübi'l- İlmiyye, 1413/1993.

Ebû Tammâm, Habîb b. Evs b. Hâris et-Tâi. Divânu Ebî Tammâm bi-Şerhịi'l-Hatîb et-Tebrîzî. Nşrr. Muhammed Abduh Azzam, 4 Cilt. Kahire: Dârü'l-Meêarif, ts.

Ferâhidî, Ebû Abdirrahmân el-Halîl b. Ahmed b. Amr b. Temîm. Kitabu'l- 'Ayn. Thk. Abdulhamîd Hindavî. 4 Cilt. Beyrut: Dârü'l-Kütübü'l-'illmiyye, 1424/2003. Girnatî, Ebû Cafer Ahmed b. İbrâhîm b. ez-Zübeyir. el-Burhân fí tertibi suveri'l- Kur'ân. Thk. Muhammed Şabânî, Fas: Vuzâretu'l-Evkāâf ve'ş-Şuuni'l-İslâmiyye, 1410/1990.

Güneş, Kadir. Arapça - Türkçe Sözlük. İstanbul: Mektep Yayınları, 2011.

Hâşimî, es-Seyyid Ahmed. el-Cevâhiru'l-belâğa fi'l-me'ânî ve'l-beyân ve'l-bedî́. Beyrut: Mektebetu'l- 'Asriyye, 1999.

Hâzin, Ebû'l-Hasen Alâüddîn Ali b. Muhammed b. İbrâhîm el-Bağdâdî. Lübâbü't-te'vil fí me'ânî́t-tenzîl. 4 Cilt. Mısır: Nezâretu'l-Me'arif, 1327/1909.

Herarî, Muhammed el-Emîn b. Abdullah el-Uremî el-Alevî. Hadaiku'r-ravhî ve 'r-rayhân. Thk. Hâş̧em Muhammed Ali b. Hüseyin Mehdî, 32 Cilt. Mekke: Dârü't-Tavḳu'n-Necât, $1421 / 2001$.

İbn Âkîl, Ebû Muhammed Bahâüddîn Abdullah b. Abdurrahmân b. Abdillâh. Şerḥu İbn-i 'Akîil. Kahire: Dârü't-Turâs, 1980.

İbn Hişâm, Ebû Muhammed Cemâllüddîn Abdülmeklik b. Hişâm b. Eyyûb el-Himyerî. esSîretü'n-nebeviyye (Sîretu İbn Hişâm). Thk. Ömer Abdusselâm Tedmurî, 4 Cilt. Beyrut: Dârü'l-Kitabi'l-Arabiyye, 3. Basım, 1410/1990.

İbn İshâk, Ebû Abdillah Muhammed b. İshâk b. Yesâr b. Hiyâr el-Mutallibî el-Kureşî, Siretu İbn İshâk. Thk. Ahmed Ferîd el-Mezîdî, 2 Cilt. Beyrut: Dârüll-Kütübü'l-'illmiyye, $1424 / 2004$.

İbn Manzûr, Ebü'l-Fazl Cemâlüddîn Muhammed b. Mükerrem b. Alî b. Ahmed el-Ensârî erRüveyfiî. Lisânu'l-'Arap. Kahire: Dârü'l-Ma'ârif, 1119.

İbn Reşîk, Ebû Ali el-Hasen b. Reşîk el-Ezdî el-Mesîlî el-Kayravânî. el-'Umde fí mehâsini'ş-şi'r ve Âdâbih ve Nakdih. Thk. Muhammed Muhyuddîn Abülhamîd, 2 Cilt. Beyrut: Dârü'l-Cîl, 1401/1981.

İbn Sacd, Ebû Abdillah Muhammed b. Sa'd el-Bağdadî. Kitabü'ț-Ṭabakāti'l-kebîr (eț-Ṭabaḳātü'lkübrâ). Thk. İhsân Abbâs, 8 Cilt, Beyrut: Dârü Sâdır, 1388/1968.

İbn Sîde, Ebû Hasan Ali b. İsmâîl b. Sîde. el-Muhkem ve'l-muhịțu'l-a'zâm. Thk. Muhammed Ali en-Necâr, 7 Cilt. Ma'hedu'l-Mahțuțat, 1393/1973.

İbnu Kesîr, Ebû'l-Fidâ İsmail b. Ömer b. Kesîr. Tefsîru'l-Kur'ân'il-Azîm. Thk. Mustafâ es-Seyyid Muhammed vd., 15 Cilt. Kahire: Mektebetü Evlâdi eş-Şeyh li't-Turâs, 1421/2000. 
İbnu'l-Esîr, Ebû'l-Feth Ziyâüddîn Nasrullâh b. Muhammed b. Muhammed eş-Şeybânî el-Cezerî. el-Meselü's-sâ'ir fí edebi'l-kâtib vesss-şấir. Thk. Ahmed el-Hufî \& Bedevî Tabâne, 4 Cilt. Kahire: Dârü Nahdâ, ts.

İsfahânî, Ebü'l-Kāsım Hüseyin b. Muhammed b. el-Mufaddal er-Râgıb. el-Müfretât fí ġarîbi'lKur'ân. Mekke: Mektebetu Nezar Mustafa el-Bâz, ts.

Karaalioğlu, Seyit K. Edebiyat Terimleri Kılavuzu. İstanbul: İnkilap \& Aka Kitaevleri, 1975.

Kazvînî vd. Şürühü't-Telhîṣ. 4 Cilt. Beyrut: Dârü'l-Kütübü'l-'İlmiyye, ts.

Kazvînî, Ebû'l-Meâlî Celâlüddîn el-Hatîb Muhammed b. Abdirrahmân b. Ömer b. Ahmed. elİżâh fị 'ulûmi'l-belâga. Beyrut: y.y., 1993.

Kelbî, Ebû'l-Münzir Hişâm b. Muhammed b. Sâib b. Bişr el-Kelbî el-Kûfî. Kitâbü'l-Eșnâm. Thk. Ahmed Zekî Paşa, Mısır: Dârü'l-Kütübü'l-Mısriyye, 1416/1995.

Kurtubî, Ebû Abdillah Muhammed b. Ahmed b. Ebî Bekir b. Ferh. el-Câmi' li Ahkkâmi'l-Kurânn. Thk. Abdullah b. Abdülmuhsin et-Türkî, 24 Cilt. Beyrût: Müessesetü'r-Risâle, $1427 / 2006$.

Mahallî, \& Süyûtî, Ebû Abdillah Celâlüddîn Muhammed b. Ahmed b. Muhammed en-Ensârî \& Ebü'l-Fazl Celâlüddîn Abdurrahmân b. Ebî Bekir b. Muhammed el-Hudayrî eș-Șâfiî. Tefsîru'l-Celâleyn. Dımaşk: Dârü İbn Kesîr, 14. Basım, 1431/2011.

Matlûb, Ahmed. Mu'cemu'l-muștelehâtu'l-Belâgīiyye ve tețavuruhâ. 3 Cilt. Beyrut: ed-Dârü'lArabiyyeti li'l-Mevsuât, 1427/2006.

Mecme'u'l-lügati'l-'Arabîyye. el-Mu'cemu'l-vasiț. Mısır: Mektebetü'ş-Şürükü'd-Devlîyye, 4. Basım, 1425/2004.

Meraği, Ahmed Mustafa. Tefsîru'l-Merấgỉ. 30 Cilt. Mısır: Şirketu Mektebeti ve Matba ati Mustafâ el-Bâbî el-Halebî ve Evlâduhu bi Mısır, 1365/1946.

Meydânî, Abdurrahmân Hasan Habanneke. el-Belâgatu'l-'Arabiyye. 2 Cilt. Dımașk: Dârü'lKalem \& Beyrut: Dârü'ş-Şâmiyye, 1416/1997.

Zebîdî, Muhammed Murtaza el-Hüseynî. "lft", Tâcü'l-'arûs min cevâhiri'l-Kāmûs. 40 Cilt. Beyrut: Dârü'l-Fikr, 1994.

Muhtar Ömer, Ahmed. Mu'cemu luġati'l-'Arabiyyetu'l-ma'asire. Kahire: 'Alemu'l-Kütüb, $1429 / 2008,1572$.

Müslim, Mustafa. Mebâhis fi't-tefsîri'l-mevdûî. 2. Baskı, Dimaşk: Dârü'l-Kalem, 1418/1997.

Ömer Nasuhi Bilmen, Kur'ân'ı-Kerîm'in Türkçe Meâli Âlisi ve Tefsîri. 8 Cilt. İstanbul: Bilmen Yayınevi, 1985.

Râzî, Ebû Abdillah Fahruddîn Muhammed b. Ömer. et-Tefsîru'l kebîr/Mefâtîhu'l-ġayb. 32 Cilt. Beyrut: Dârü'l-Fikir, 1420.

Sâbunî, Muhammed Ali. Safvetu't-tefâsîr. 4 Cilt. Beyrut: Dârü'l-Kur'âni'l-Kerîm, 4. Basım, $1402 / 1981$.

Sa îdî, Abdu'l-Muteal. en-Naẓmu'l-Fenniyyu fi'l-Kur'ân. Kahire: Mektebetü'l-Âdâb li'n-Neşri ve't-Tevzî́, 1439/2018.

Salihu'l-Aliyi's-Salih \& Emîne eș-Șeyh Süleymâni'l-Ahmed, "vbh", Mu'cemu'ș-șâfî fi'lüg̉ati'l'Arabîyye.

Seber, Abdülkerim. İmam Ebû Mansur Muhammed Mâtürîdî'nin "Te'vilâtü'l-Kur'ân"ında Necm Sûresi Tefsîri: Tercüme - Tahlîl - Mukayese. Bilimname 11. 2006/2, 97-139.

Sekkâkî, Ebû Yakup Sirâcüddîn Yûsuf b. Ebî Bekir b. Muhammed b. Ali el-Hârizmî. Miftâhu'l'ulûm. Thk. Abdulhamîd el-Hindâvî, Lubnan: Dârü'l-Kütübi'l- '̇lmiyye, 1420/2000.

Selâme, Muhammed Hüseyin. el-İ'câzü'l-belâgì fi'l-Kur'ân-il Kerîm. 2 Cilt. Kahire: Dârü'l-Âfâkịi'l'Arabiyye, 1423/2002. 
Semîn el-Halebî, Ahmed b. Yusuf b. Abduddâim. 'Umdetu'l-ḥuffaz fí tefsîri eşrefi'l elfâzạ. Beyrut: Dârü'l-Kütübi'l- '̇lmiyye, 1997.

Subhî, Salih. Mebâhis fì 'ulumi'l-Kur'ân. Beyrut: Dârü'l-'ilim li'l-Melâyyin, 10. Basım, 1977.

Sûyütî, ed-Dürrü'l-menșûr fi't-tefsîri bi'l-me’sûr. Thk. Abdullah b. Abdulmuhsin et-Türkî, 17 Cilt. Kahire: Merkezu Hecer, 1424/2003.

Süyûtî, Ebü'l-Fazl Celâlüddîn Abdurrahmân b. Ebî Bekir b. Muhammed el-Hudayrî eş-Şâfiî. elİtkāan fì 'ulûmi'l-Ḳur'ân. Beyrut: Müessesetu Risâletu Nâşirün, 1469/2008.

Süyûtî, Lübâbu'n-nüküll fi esbâbi'n-nüzul. Beyrut: Müessesetu'l-Kütübi'l-Sekāfiyye, 1422/2002.

Şihabuddin Ebü Senâ Mahmud b. Süleyman. Hüsnü't-tevvesul ilâ șana'ati't-tarasul. Mısır: Matba'atü'l-Vehbîyye, 1398.

Taberî, Ebû Cafer Muhammed b. Cerîr b. Yezîd. Câmi'u'l-beyân 'an te’vîli âyi'l-Kur'ân. Thk: Abdullah b. Abdulmuhsin et-Türkî. 26 Cilt. Dârü'l-Hicir, 1422/2001.

Tehânevî, Muhammed Ali. Keşşâfu ișțilaḥati'l-fununi ve'l-'ulûm. thk. Ali Dahrüc, 2 Cilt. Beyrut: Mektebetü Lübnan Nâşirun, 1997.

Tîbî, Şerefüddîn el-Hüseyin b. Abdullah b. Muhammed. et-Tibyân fî 'İlmi'l-Me'ânî ve'l-Beyân. Thk. Abdüssettar Hüseyin Zemmût, Beyrut: Dârü'l-Cîl, 1996.

Vahidî, Ebû'l-Hasan b. Ali b. Ahmed b. Muhammed el-Vahidî en-Nîsâbûrî. Esbâbu'n-nüzul. Thk. Usam b. Abdulmühsin, el-Humeydân, ed-Demmam: Dârü'l-Islâh, 2. Basım, 1416/1992.

Yakup, Emil Bedi'. el-Mu'cemu'l-mufașșal fi'l-lügati ve'l-edeb. Beyrut: Dârü'l-'Illim li'l-Melâyyin, ts.

Zemahşerî, Ebû'l-Kāsım Mahmûd b. Ömer. Tefsîru'l-keșşâf 'an hakāikịi ġavâmidi't-tenzîl ve 'uyuni'l-ekāoîli fî vucuhi't-te'vîl. Thk. Adil Ahmed Abdulmevcud \& Ali Muhammed Mu'avid, 6 Cilt. Riyad: Dârü'l-Abikân, 1998.

Zerkeşî, Bedruddin Muhammed b. Abdullah. el-Burhân fî 'ulûmi'l-Kur'ân. Thk. Yusuf Abdurrahman vd. 4 Cilt. Lübnan: Dârü'l-Meârife, 1410/1990. 